\title{
Tulane
}

Tulane Economics Working Paper Series

\section{Applying Behavioral Economics to the Public Sector}

\author{
James Alm \\ Department of Economics \\ Tulane University \\ jalm@tulane.edu
}

\author{
Carolyn J. Bourdeaux \\ Department of Public Management and Policy \\ Andrew Young School of Policy Studies \\ Georgia State University \\ cbourdeaux@gsu.edu
}

Working Paper 1405

April 2014

\begin{abstract}
"Behavioral economics", or the application of methods and evidence from other social sciences to economics, has increased greatly in significance in the last two decades. In this paper we discuss the basic elements of behavioral economics. We then assess several applications of behavioral economics to the analysis of the public sector, including specific applications to public economics and, importantly, to the closely related area of public budgeting. We conclude with suggestions on - and predictions of - topics in which future applications should prove useful.
\end{abstract}

Keywords: behavioral economics, public economics, public budgeting JEL codes: H0, H3, H61, H83 


\title{
APPL YING BEHA VIORAL ECONOMICS TO THE PUBLIC SECTOR
}

\author{
James Alm and Carolyn J. Bourdeaux*
}

\begin{abstract}
"Behavioral economics", or the application of methods and evidence from other social sciences to economics, has increased greatly in significance in the last two decades. In this paper we discuss the basic elements of behavioral economics. We then assess several applications of behavioral economics to the analysis of the public sector, including specific applications to public economics and, importantly, to the closely related area of public budgeting. We conclude with suggestions on - and predictions of - topics in which future applications should prove useful.
\end{abstract}

Key Words: Behavioral economics, public economics, public budgeting.

JEL Codes: H0, H3, H61, H83.

*James Alm: Department of Economics, Tulane University, 6823 St. Charles Avenue, 206 Tilton Hall, New Orleans, LA 70118 (phone +1 504862 8344; fax +1 504865 5869; email jalm@ @ulane.edu).

Carolyn J. Bourdeaux: Department of Public Management and Policy, Andrew Young School of Policy Studies, Georgia State University, 14 Marietta Street, NW, Atlanta, GA 30303 (phone +1 4044130013 ; fax +1 404413 0104; email cbourdeaux@gsu.edu). We are grateful to Julio López Laborda, Jorge Martínez-Vázquez, and two anonymous referees for many helpful comments. 


\section{Introduction}

Most positive approaches to analyzing behavior have traditionally been based on variants of the standard economic model of behavior, in which an individual is assumed to be a fully rational, selfcontrolled, and maximizing decision-maker. However, it is increasingly recognized that individuals do not always behave in ways that are consistent with this standard model. "Behavioral economics" is a catch-all term that has been used to describe this development. Behavioral economics can be loosely defined as the application of methods and evidence from other social sciences like sociology, anthropology, and, especially, psychology to economics, and recent applications expand beyond the social sciences to "hard" sciences like neuroscience. At its core is the belief that increasing the realism with which individual behavior is seen will improve the ability to predict behavior and to devise policies. Its influence in economics has increased enormously in significance in the last two decades, transforming the ways in which economists think about individual behavior. Its influence in public economics has been quite strong, in such areas as compliance, savings incentives, tax incidence, time consistent policies, and social insurance.

Somewhat surprisingly, the closely related field of public sector budgeting theory has been largely uninfluenced by behavioral economics. Budgeting would seem to be an obvious place to extend these ideas. Most people involved in the analysis of public sector budgeting would not find it odd that the choices made by individuals can be influenced by such behavioral economics notions as "framing", "loss aversion", and "reference points", and that some of the anomalies of temporal discounting might mirror public sector choices around capital outlay, debt, and financing pensions.

In this paper we discuss the basic elements of behavioral economics. We then assess applications of behavioral economics to the analysis of the public sector, including specific applications to public economics and, importantly, also to public budgeting. Our discussion is comprehensive, but we must of course be somewhat selective in our choice of topics and references. We conclude with suggestions forand predictions of - topics in which future applications should prove useful. 


\section{What is "behavioral economics"?}

\subsection{Some basic notions}

The standard neoclassical economic model of human behavior is based on several main assumptions: individuals are rational, they have unlimited willpower, and they are purely self-interested. While these assumptions may be a useful starting point for the analysis of individual behavior, there is increasing evidence that they are inaccurate and unrealistic depictions of many, perhaps most, individuals. Indeed, there is growing acceptance that, contrary to the standard neoclassical approach:

- they are affected by the ways in which choices are "framed" (e.g., "reference points", gains versus losses, "loss aversion", "risk-seeking behavior", "status quo bias")

- individuals face limits on their ability to compute (e.g., "bounded rationality", "mental accounting")

- they systematically misperceive, or do not perceive at all, the true costs of actions (e.g., "fiscal illusion", "saliency", "overweighting" of probabilities)

- they face limits on their "self-control" (e.g., "hyperbolic discounting", Christmas savings clubs, automatic enrollment programs)

- they are motivated not simply by self-interest, but also by notions of fairness, altruism, reciprocity, empathy, sympathy, trust, guilt, shame, morality, alienation, patriotism, social customs, social norms, and many other objectives, and

- they are influenced by the social context in which (e.g., diversity), and the process by which (e.g., voting rules), decisions are made.

As emphasized by Congdon, Kling, and Mullainathan (2011), these so-called "deviations" can be classified into three broad areas: non-standard preferences (like other-regarding preferences), imperfect optimization (stemming from, say, limited computation abilities), and bounded self-control (as demonstrated by hyperbolic discounting).

In short, individuals are not always the rational, outcome-oriented, self-controlled, selfish, and egoistic consumers envisioned by much of our standard theory. Behavioral economics uses these deviations from the standard assumptions as the starting point for a more realistic view on how individuals make choices. Indeed, behavioral economics opens up a new justification for government intervention in markets (beyond the traditional one based on market failures): when individuals do not optimize even in otherwise well-functioning markets, there may be welfare gains from government actions that help improve 
individual choices. As discussed in detail by Rabin (1998), Camerer and Lowenstein (2004), McCaffery and Slemrod (2006), Wilkinson (2007), Angner and Loewenstein (2010), and Congdon, Kling, and Mullainathan (2011), among others, "behavioral economics" can be broadly defined as an approach that uses methods and evidence from other sciences to inform the analysis of individual and group decision making. For more "popular" discussions, see Ariely (2008), Thaler and Sunstein (2008), and Kahneman (2011).

The emergence of behavioral economics is sometimes viewed as a recent phenomenon. However, the relevance of behavioral insights has long been part of economics, including the works of many of the most prominent economists, from Adam Smith's The Theory of Moral Sentiments (1759), to Francis Edgeworth's Mathematical Psychics (1881), to Amilcare Puviani’s Teoria Della Illusione Finanziaria (or The Theory of Fiscal Illusion) (1903), to Irving Fisher's The Money Illusion (1928), and to John Maynard Keynes' The General Theory of Employment, Interest, and Money (1936). Even in the last sixty years or so, economists like Herbert Simon (Administrative Behavior, 1947), George Katona (Psychological Analysis of Economic Behavior, 1951), and Tibor Scitovsky (The Joyless Economy: The Psychology of Human Satisfaction, 1976) have incorporated, and indeed emphasized, the importance of psychology in individual decision-making. In this light, the origin of the name "behavioral economics" is somewhat obscure. One of the first uses was by Boulding (1958), who wrote that there will be movement toward "... study of those aspects of men's images, or cognitive and affective structures that are more relevant to economic decisions". Given the essential role of psychological insights in the field, together with the obvious truism that all economics concerns "behavior" in one form or another, a more descriptive name for the field is perhaps “cognitive economics", as recognized early on by Boulding (1958).

\subsection{Some common criticisms}

The use of behavioral methods is not without some criticisms. A common one is that there is no single unified "theory" of individual behavior that applies across the various individual behaviors. Indeed, a "typical" behavioral economics paper, at least in the earlier days, often started with some anomaly that standard theory could not easily explain, proceeded to a specific model of the bias, and then concluded with 
an experimental demonstration of the "correct" explanation. Such an approach clearly lacks the generality that is commonly associated with the neoclassical paradigm. However, progress is clearly being made in modeling individual behavior. Further, as we argue throughout, we believe that it is futile to believe that one single model or modeling approach can hope to explain the diversity of human behavior. A related concern is that, in the absence of such a unified theory, making judgments about the social welfare implications of policies is problematic. However, progress is also being made on the welfare foundations of behavioral economics (Bernheim and Rangel 2009).

A second criticism of behavioral methods is that the focus is often on individual behavior (as well as on tests of the underlying assumptions of individual behavior), rather than on the broader dimension of aggregate, group, or market behavior. Closely related to this criticism is a third one: although individuals may not always behave rationally, individual bias may well "wash out" in the aggregate, and it is aggregate behavior that is most relevant for economics. As noted by Glaeser (2004), "[t]he great achievement of economics is understanding aggregation... Our discipline has always been about the wealth of nations, not individuals". Indeed, Becker (1962) demonstrated long ago that, as long as some individuals in a market respond predictably to incentives, markets will perform as predicted; that is, individual anomalies are less important than aggregate rationality. Even so, markets are the aggregation of individuals, so that a better understanding of individual behavior must necessarily help in understanding market behavior. Further, empirical evidence suggests that anomalies arising from individual behavior often remain even when the individual results are aggregated. Finally, to claim that behavioral economists do not consider the aggregate implications of behavioral issues is simply untrue, as shown by the work of Chetty, Looney, and Kroft (2009) on tax salience, among many others. Indeed, the ways in which individuals interact with other individuals in social settings is central to much of behavioral economics.

A final criticism of behavioral economics is the paternalistic implications of many behavioral insights. If individuals have a limited ability to compute, if they do not perceive the true costs of actions, if they face limits on their self-control, if they are affected by the ways in which choices are framed, if they are influenced by the social context in which (and the process by which) decisions are made, and if they are 
weakly motivated, then giving them more options in choosing, say, where to invest their retirement savings may not make them better off. Instead, some circumscribed choices (e.g., a "default" investment option in savings plans) may make them better off. This is the underlying motivation for the "soft paternalism" or "libertarian paternalism" notions that are most fully articulated in Thaler and Sunstein (2008), especially in the context of the United States.

However, to many critics, moving forward with these paternalistic policy proposals is premature and unjustified. They argue (again) that, although individuals may often make poor choices, aggregate rationality cancels out individual psychology. Glaeser (2006) also argues that individual irrationality is not limited to individuals who make choices in markets but extends to individuals in all dimensions of their behavior, including those who make choices about government policy; because individuals have a greater incentive to choose wisely in market settings than in government settings, he concludes that behavioral economics actually strengthens the case for limited government.

Still, we believe that it is hard to avoid the conclusion that analysts make normative judgments about "good" policy all the time. What behavioral economics emphasizes is that it is precisely because human decisions are so sensitive to the context in which they are framed that we need to recognize more fully the role that our underlying cognitive processes - sometimes called our "default-settings" - play in our decisions. As David Foster Wallace said in his 2005 commencement speech at Kenyon College, all of us are a slave to our "natural hard-wired default-setting, ... which is to be deeply and literally self-centered and to see and interpret everything through this lens of self". He further argues that we need to work hard and we need help - in getting free of this default-setting. It is in this sense that behavioral economics, with its soft paternalism, may be able to help individuals in making decisions that, even from their own perspective, make them better off.

\subsection{Some specific elements of behavioral economics (1): Individual framing effects theory}

One strand of behavioral economics deals mainly with individual behavior. Many of the individual behaviors that diverge from neoclassical predictions involve some form of "frame dependence", in which 
an individual's decision depends upon how the choice is presented. Frame dependence is typically related to some psychological predisposition or some cognitive limitation of the individual.

One factor here is that individuals apparently adapt to an unchanged environment and perceive stimuli relative to this environment. Many individuals react much differently to gains than to equal-butopposite valued losses. Individuals may therefore act on the basis of a "value function" (rather than the utility function in economic models). The value function is assumed to depend upon changes in income from some "reference point", rather than the level of income itself. The value function is also assumed to be steeper for losses than for gains because a loss in income is disliked much more than an equal gain, and it is concave for gains ("loss aversion") but convex for losses ("risk seeking"), so that an individual may exhibit risk-averse behavior when confronted with risky but positive gambles, while the same individual may become a risk-lover when faced with gambles that involve (net) possible losses.

Individuals also often misperceive the true costs of their actions. The standard model of individual behavior assumes that individuals are fully aware of these costs (and their associated benefits). However, there is much evidence that individuals are often unaware or at least inattentive to some types of incentives; in such cases, observed behavior will clearly differ from behavior predicted by standard models of individual optimization. Such inconsistencies seem likely in the case of taxes, given the complexity, opaqueness, and informational asymmetries of tax systems. These types of misperceptions have led to suggestions that voters will misperceive the true tax price of public goods, often focusing only on the immediate cost of public goods and not recognizing the future burdens implied by these programs, a phenomenon referred to as "fiscal illusion". A related aspect is "saliency", which refers to the visibility of the costs and benefits of one's actions. In the case of taxes, individuals seem unlikely to be fully aware of the true tax-inclusive price of a good, especially when a tax is included only in the posted price of the good and not as a separate piece of information.

Still another factor is that people do not engage in exponential discounting but instead engage in discounting that is better described by a quasi-hyperbolic functional form (Laibson 1997, 1998). In particular, there is an immediacy effect that causes the discount rate to be very high when a person has to 
choose between a benefit/cost immediately evaluated against a benefit/cost in the future. An often used example is that people appear to prefer $\$ 100$ now rather than $\$ 110$ tomorrow. However, if told that they can choose between receiving $\$ 100$ one year from now versus $\$ 110$ in a year and a day, most will then choose the $\$ 110$. In the standard model of discounting, these choices are exactly the same and people should make exactly the same choice in both contexts; however, since they do not, this indicates that the discount rate for a future benefit is higher in the first instance when there is the effect of immediacy than in the second instance.

A related notion is that individuals may not be able to make all of the computations implied by standard optimization given, say, limits on time or cognitive abilities. In the face of these limitations, they may instead apply "heuristics" or "rules of thumb" that allow them to "satisfice" rather than to fully optimize. Perhaps the most complete development of this modeling strategy is the "bounded rationality" of Simon (1955).

A final aspect is that individuals are motivated by a wide range of factors, including self-interest (narrowly defined) but also by notions of fairness, altruism, reciprocity, empathy, sympathy, trust, guilt, shame, morality, alienation, patriotism, social customs, social norms, and many other objectives. Some of these motivations (e.g., guilt, altruism) are often modeled by introducing additional elements in the individual's objective function (e.g., by adding a non-pecuniary (or psychic) cost associated with evading one's own tax liability, by adding a "warm glow" associated with making a charitable contribution). Some other motivations (e.g., fairness, reciprocity) require introducing group interactions; these elements are discussed later.

Also important is individual behavior under uncertainty, and there are now various formalizations of "non-expected utility theory" that have been applied to individual choices. One factor that emerges from these efforts is the way in which individuals perceive probabilities. There is overwhelming evidence that individuals "overweight" the low probabilities that they face in some situations, like tax compliance; that is, even when fully informed, individuals systematically act as if the audit probability that they face is much higher than its actual level. If an individual gives more subjective weight to the probability of an outcome 
than implied by its objective level, then individual behavior will clearly be different than that predicted by standard expected utility theory. More generally, individuals may act on the basis of "subjective probabilities".

There are numerous examples of these non-expected utility theories, including (but not limited to) rank dependent expected utility theory, first order and second order risk aversion, regret theory, disappointment theory, non-additive probabilities, and ambiguity theory; the most well-known is likely prospect theory of Kahneman and Tversky (1979). Relative to expected utility theory, these models change the "probability" that an individual perceives and the "objective function" that he or she pursues. In doing so, they considerably complicate the analysis of the individual decision, but they can also generate predictions that better approximate observed levels, especially if they have overweighting of probabilities.

\subsection{Some specific elements of behavioral economics (2): Social interactions theory}

A second strand of behavioral economics focuses more on group behavior, which we classify as the "social interactions theory" strand. There is abundant evidence that individuals are influenced by the social context in which, and the process by which, decisions are made and that they are motivated not simply by self-interest but also by group notions like social (or group) norms, social capital, social customs, appeals to patriotism or conscience, or feelings of fairness, altruism, reciprocity, empathy, sympathy, trust, guilt, shame, morality, and alienation, all of which depend upon the individual's interactions with a larger group.

There are various aspects of these social interactions. The most straightforward aspect simply recognizes the obvious fact that individuals are not the same and that they cannot be perceived as a homogeneous group. Some individuals may be motivated only by financial outcomes, but others may have different preferences, including nonfinancial considerations like guilt, altruism, fairness, or reciprocity. Further, the process by which a different outcome is attained often matters. In short, people exhibit great diversity in their behaviour, and this "full house" of behaviors must be recognized (Alm 2012).

Another aspect might be termed a "social contribution dilemma" (or a "free-rider problem"), where personal gains work against the collective good. More precisely, Dawes (1980) defines a social dilemma as a situation in which an individual's interests are opposed to those of the community. By acting selfishly, an 
individual can benefit. However, if most individuals similarly decide to maximize their own individual profit, then everyone is harmed because the public goods are not provided. The crucial issue here is how to influence the willingness to cooperate.

A last and closely related approach to social interactions emphasizes that much individual behavior can be broadly viewed as a "psychological contract" between individuals (and between individuals and government). Central to this contract is the broad notion of a "social norm" of behavior (Akerlof 1980; Elster 1989; Young 1998). A social norm represents a pattern of behavior that is judged in a similar way by others and that is sustained in part by social approval or disapproval. Put differently, a social norm is a recognized, customary, and self-reinforcing pattern of behavior in which everyone participates, given the expectation that everyone else will also participate. Put still differently, a social norm is an informal rule of behavior that individuals follow for reasons largely distinct from the fear of legal penalties.

Consequently, if others behave according to some socially accepted norm of behavior, then the individual will behave appropriately; if others do not so behave, then the individual will respond in kind. The presence of a social norm is also consistent with many other approaches that incorporate similar notions of social interactions, such as those that recognize some form of other-regarding preferences. Indeed it is hard to think of any type of social interaction that is not governed in some way or some degree by a social norm.

There are many suggested rationales for the existence of social norms. Efficiency is often proposed; that is, a social norm may help to maximize social welfare (Akerlof 1980), to prevent market failures (Coleman 1990), or to reduce social costs (Homans 1961); a social norm may also evolve as a Nash equilibrium of a coordination game or as a cooperative equilibrium of a prisoner's dilemma game (Ullmann-Margalit 1977; Young 1998). However, although social norms typically reduce transactions costs, many social norms may in fact be highly inefficient (e.g., discrimination, etiquette, retribution). They may also generate clear winners and losers. Regardless, it seems unlikely that a social norm evolves randomly. 
Social norms are enforced by different mechanisms. Those social norms that enhance efficiency may be maintained by a pure coordination motive. Other social norms may be sustained by the threat of social disapproval. Relatedly, enforcement may occur through internalizing social norms of proper conduct via, say, shame or guilt.

Overall, the existence of a social norm suggests that the nature of one's social interactions with others affects one's own behavior. Prominent examples of theories that include these social interactions include the fairness model of Rabin (1993), "ERC" (or equity, reciprocity, and completion) of Bolton and Ockenfels (2000), "inequality aversion" of Fehr and Schmidt (1999), "reciprocal altruism" of Cox, Friedman, and Sadiraj (2008), among others. These models all introduce some elements of interdependent, or other-regarding, preferences.

The next sections apply these behavioral notions to different aspects of the public sector.

\section{Some applications to public economics}

In this section, we discuss some of the areas in public economics to which behavioral economics has been usefully applied; our discussion here is necessarily brief and overly selective, and focuses on only a few of the many areas to which behavioral economics have been applied. In a later section, we present in some detail a specific area of public economics based on some of our own research. Our intention is to focus on the positive aspects of these studies, rather than on their normative aspects; that is, we discuss the effects of different policies on behavior, and we largely ignore the normative evaluation of these effects are good or bad.

Note that many tests of behavioral economics theories have taken place via laboratory experiments, at least early on, largely because experimental methods allow the control necessary for distinguishing behavioral explanations from standard ones. However, more recent tests of behavioral theories have employed the usual methods of economists, including controlled field experiments and standard empirical methods. 


\subsection{Charitable giving}

The standard approach to charitable giving is based on the assumption that an individual who gives away some amount of income must benefit in some way from this gift, typically because the public benefits of the gift enter into the giver's utility function. However, as shown by Warr (1982), Roberts (1984), and Bergstrom, Blume, and Varian (1986), this model predicts that, if giving is a pure public good, then government grants to charities will perfectly crowd out private donations. Indeed, Andreoni (1988) demonstrates that this approach predicts that private contributions should essentially vanish in large economies. Since complete crowding out is clearly not observed, additional motivations for giving have emerged, such as "warm glow" giving (Andreoni 1989), where an individual derives some direct and private utility from giving. Given the deductibility of charitable contributions, the role of tax incentives has also been frequently examined, and there is an immense empirical literature that tests various aspects of these theories (Clotfelter 1985; Andreoni and Payne 2013).

More recently, however, it has become recognized that giving is an inherently social act, in which the various social interactions become important. As noted by Andreoni and Payne (2013), someone is watching as one makes a gift, people are judging each other's actions, and somebody is asking for the gift. In such a setting, the nature of these social interactions emerges as a major factor in giving.

Several recent studies examine these social interactions. For example, Andreoni and Bernheim (2009) demonstrate that, when an individual places some value on being seen as "fair", then an "audience" for one's giving can either increase or decrease one's feeling of altruism, with correspondingly different impacts on giving; their experimental results provide strong support for this hypothesis. Andreoni and Rao (2011) use experimental methods to examine the ways in which altruism is affected by interactions between givers and receivers in a dictator game, and find that communication by the receiver with the giver increased giving; however, when only the giver speaks, choices become more selfish. They conclude that communication influences altruistic behavior, mainly by increasing empathy. Hungerman (2009) and Fong and Luttmer (2011) examine the impact of diversity (racial, religious, ethnic) on individual donations to private charities, and they find that diversity generally has a negative effect on charitable donations. 
DellaVigna, List, and Malmendier (2012) design a controlled field experiment to test whether an individual gives due to altruism or warm glow, and or whether the individual dislikes saying no due to, say, social pressure. They use a door-to-door fund-raiser in which some households are informed about the exact time of solicitation with a flyer on their doorknobs, and find that the flyer reduces giving by a significant amount. They conclude that social pressure is an important determinant of door-to-door giving. ${ }^{1}$

\subsection{Voluntary contributions to public goods}

These and other studies demonstrate the inherent social nature of charitable giving. This work is closely related to the literature on voluntary contributions to public goods. Following Samuelson (1954), the standard theory of public goods concludes that the Nash equilibrium is characterized by zero voluntary contributions to public goods, as individuals attempt to "free ride" on the contributions of others. However, there are numerous examples from the naturally occurring world in which many individuals contribute positive amounts to public goods (e.g., public radio, volunteer work, and charitable donations). Early on, experiments were the main method used both to determine the circumstances under which individuals will contribute and to determine mechanisms that will help overcome the free rider problem. Field experiments are now increasingly used.

A typical "voluntary contributions" public goods experiment begins by assigning student subjects to groups. Subjects are endowed with tokens and are isolated from each other. Each subject is offered two possible "investments", one in a private good and one in a public good. The private good investment has higher returns for that individual, but the public good investment provides a return to all members of the group; that is, the public good investment is both nonrival (because all members of the group derive the same benefit from any member's contribution) and nonexclusive (because subjects who do not contribute to the public good investment still receive the same group return). Subjects are then asked to choose an allocation of tokens between the investments. Because the total social return is greater for the public good than for the private good, the socially efficient outcome is for everyone to contribute fully to the public

\footnotetext{
${ }^{1}$ See also List and Lucking-Reiley (2002), Gneezy and List (2006), Landrey et al. (2006, 2010), Karlan and List (2007), and List and Price (2009) for other field experiments on charitable giving.
} 
good. However, as with the standard prisoner's dilemma game, each individual has an incentive to keep all of his or her tokens because the private good investment has a higher personal return than the public good investment. This contribution game is then repeated for a number of rounds, and the level of actual contributions is compared to the Nash equilibrium prediction (zero contributions) and the socially efficient outcome (full contributions). There are numerous variants on this basic design (e.g., one-shot versus repeated games, threshold or provision point payoffs, incentive compatible mechanisms, experienced versus inexperienced subjects, fixed versus random subject assignment, small versus large group sizes, nocommunications versus communication sessions).

All of these experiments aim to answer the core questions of public goods provision. How much are people willing to contribute to a public good? Of particular relevance to behavioral public economics, why do they contribute at all? It is noteworthy that many recent studies have introduced new theories based upon behavioral economics. These models introduce such factors as: altruism (Becker 1974; Andreoni and Miller 2002), impure and warm-glow altruism (Andreoni 1989, 1990), inequality aversion (Fehr and Schmidt 1999; Bolton and Ockenfels 2000), confusion versus altruism (Andreoni 1995), and reciprocity (Sugden 1984). Experimental and field studies find strong support for the relevance of social interactions theories in public good contributions. In particular, Ledyard (1995) concluded that the results from the varied experiments, while often contradictory, suggested several "stylized facts", including the important results that: many subjects contribute to a public good, sometimes in significant amounts, despite standard predictions of free rider behavior; there is substantial individual variation in contributions, suggesting that individuals are motivated by different considerations; subjects in initial rounds contribute halfway between the socially efficient level and the free riding level; contributions decline over time but eventually stabilize at above free rider levels; and contributions can be influenced by such factors as face-to-face communication (e.g., "cheap talk"), pictures of participants (e.g., "beauty"), and disclosure of others' contributions.

\subsection{Salience and taxation}


The standard approach to analyzing individual responses to taxes assumes that individuals are fully aware of all relevant aspects of the tax system. However, there are increasing numbers of studies that demonstrate that this knowledge is often not present, and that the absence of this knowledge has significant impacts on outcomes.

For example, Chetty, Looney, and Kroft (2009) examine the impact of tax "salience" on behavior, where salience refers to the visibility to consumers of the tax-inclusive price. When a tax rate is included in the posted price of the good, the total tax-inclusive price is more visible, but the tax rate itself may be less clear. Does this salience affect the outcome? Using a controlled field experiment in which a grocery store posted tax-inclusive prices for a range of products, they find that this intervention reduced demand for the treated products by 8 percent. Their results suggest that consumers underreact to taxes that are not salient, which affects both the incidence and the excess burden of the taxes. In related work, Chetty, Friedman, and Saez (2013), Chetty and Saez (2013) find that individual awareness of the tax benefits of the Earned Income Tax Credit (EITC) affects the take-up rate (and subsequent earnings of recipients) of the EITC, and Cabral and Hoxby (2012) and Bradley (2013) demonstrate the individuals do not always recognize the amount and the timing of their property tax payments. Chetty (2012) demonstrates that these types of informational frictions can have significant impacts on estimated behavioral elasticities.

Related work looks more generally at the responses to taxes. Taxes can cause real changes in individual behavior; that is, the return on the taxed activity is reduced because of the tax, and people should tend to participate less in the taxed activity. However, these responses depend upon knowledge of the tax. One type of response that has often been studied is some aspect of labor supply response, with experimental methods typically used in the analysis. These studies often find that individuals do not respond as predicted by the standard model due to their perceptions - or misperceptions - of the tax. For example, Blumkin, Ruffle, and Ganun (2008) find that subjects respond differently to an income tax than to an equivalent consumption tax largely because the timing of the tax payments is opaque. Similarly, Sausgruber and Tyran (2005) examine differential subject responses to taxes that, at least in theory, are equivalent (e.g., direct versus indirect taxes), and they also find differential responses, despite the 
predictions of theory. Other papers examining real responses to taxes have taken varied approaches. de Bartolome (1995) investigates whether people respond to average or marginal tax rates. He showed tax schedules to students, and asked them to choose between an untaxed (but lower return) and a taxed (and higher return) savings vehicle, as returns were varied. His experimental results suggest that many subjects appeared to base their decision on the average tax rate rather than the marginal tax rate as assumed in most analyses. Baron and McCaffery (2003) also show that individuals may not accurately perceive the relevant tax burden; that is, they tend to underestimate the total tax burden when the burden is distributed across many smaller taxes.

\subsection{Savings incentives}

The standard approach to the analysis of individual savings relies upon the life-cycle model, in which an individual saves largely as a way of smoothing consumption over the lifetime. However, dissatisfaction with this approach has grown over time, given the apparent failure of many of its basic predictions on such fundamental things as the extent of savings and the response of savings to changes in intertemporal prices. Behavioral economics has been extensively applied to savings in the last 20 years, with two main areas of behavioral concerns: knowledge/sophistication and self-control. With the emergence of Laibson's $(1997,1998)$ work on quasi-hyperbolic discounting, work in both areas has grown enormously.

Issues of knowledge/sophistication arise from the complexity of intertemporal planning. To determine the solution of a standard life cycle problem, an individual would require a high level of sophistication and extensive information on pertinent economic parameters. However, as Bernheim (1994) demonstrates, much of the population appears ill-equipped to make even the most basic economic calculations. Self-control refers to the ability to follow through on intertemporal plans that require an individual to forego short-term gratification. While the life cycle hypothesis implicitly assumes that selfcontrol is perfect, a large body of psychological research suggests that imperfect self-control lies at the heart of many intertemporal decision-making problems (Ainslie 1975, 1991; Thaler and Shefrin 1981; Schelling 1984; Maital 1986; Shefrin and Thaler 1988; Loewenstein and Prelec, 1992). 
These observations have generated a large literature on ways in which savings incentives can be presented to individuals, for example, as active versus passive (or pre-commitment and/or automatic) decisions, in order to overcome self-control problems. ${ }^{2}$ Some programs require participants to make an active decision to participate; in other programs, the automatic default option may be to participate, so that the decision to opt out of the incentive program requires an active decision. There is now considerable evidence that making participation the default option has a significant positive impact on savings within retirement accounts (Madrian and Shea 2001; Thaler and Benartzi 2004; Duflo et al. 2006; Finkelstein 2009; Card and Ransom 2011). Chetty et al. (2013) provide recent evidence that defaults also have a significant positive impact on total savings, while more traditional tax incentives have virtually no impact on total savings.

There is also a large literature on how financial education may affect savings. This work is based mainly on the notion of cognitive limitations that affect an individual's ability to make the complicated decisions necessary in financial planning, although this work also sometimes recognizes the self-control aspects noted earlier. These studies almost uniformly demonstrate several basic findings: most individuals lack the knowledge to devise rational financial plans, most individuals in fact do not engage in serious and sophisticated financial planning, and few people make use of available tools. These findings have led to numerous policy suggestions, together with examinations of their effectiveness including such programs as simplification of savings programs (Choi, Laibson, and Madrian 2009), automatic enrollment options (Carroll et al. 2009; Karlan et al. 2010), and enhanced school- (Bernheim, Garrett, and Maki 2001) or workplace-education programs (Bernheim and Garrett 2003; Duflo and Saez 2003; Bernheim, Bayer, and Scholz 2009). The policies with the most consistent impacts are the simplification programs and the automatic enrollment options; the impacts of education programs are quite mixed.

\section{A specific application in public economics: Tax compliance}

\footnotetext{
${ }^{2}$ There is also a similarly motivated literature on education effects in medical care choice (Abaluck and Gruber 2009; Kling et al. 2009) and in college student financial aid choice (Dynarski and Scott-Clayton 2006; Bettinger et al. 2009), often with similarly ambiguous results.
} 


\subsection{Theoretical considerations}

The standard theoretical model used in nearly all research on tax compliance begins with the economics-of-crime model, first applied to tax compliance by Allingham and Sandmo (1972). Here a rational individual is viewed as maximizing the expected utility of the tax evasion gamble, weighing the benefits of successful cheating against the risky prospect of detection and punishment, and the individual pays taxes because he or she is afraid of getting caught and penalized if he or she does not report all income. This "portfolio" approach gives the plausible and productive result that compliance depends upon audit rates and fine rates. Indeed, the central point of this approach is that an individual pays taxes because of this fear of detection and punishment.

To illustrate this implication more precisely, consider the simplest form of the standard model. An individual is assumed to receive a fixed amount of income $I$, and must choose how much of this income to report to the tax authorities and how much to underreport. The individual pays taxes at rate $t$ on every dollar $R$ of income that is declared or reported, while no taxes are paid on underreported income. However, the individual may be audited with a fixed probability $p$; if audited, then all underreported income is discovered, and the individual must pay a penalty at rate $f$ on each dollar that he or she was supposed to pay in taxes but did not pay. The individual's income $I_{C}$ if caught underreporting equals income less taxes paid on reported income less penalties on unreported taxes; if underreporting is not caught, income $I_{N}$ is income less taxes paid on reported income, so that $I_{C}$ and $I_{N}$ are defined as

$$
\begin{aligned}
& \text { (1) } I_{C}=I-t R-f[t(I-R)] \\
& \text { (2) } I_{N}=I-t R .
\end{aligned}
$$

The individual is then assumed to choose reported income to maximize expected utility, or

$$
\text { (3) } \quad E U(I)=p U\left(I_{C}\right)+(1-p) U\left(I_{N}\right) \text {, }
$$

where $E$ is the expectation operator and utility $U(I)$ is a function only of income. This optimization proceeds using standard methods.

This economics-of-crime approach gives the sensible result that compliance depends upon enforcement. Indeed, it is straightforward to show with comparative statics analysis that reported income 
increases with an increase either in the probability of detection or in the penalty rate. However, this approach also concludes that an individual pays taxes only because of the economic consequences of detection and punishment. The many extensions of this portfolio approach within the economics-of-crime approach considerably complicate the theoretical analyses, and generally render clear-cut analytical results impossible. Nevertheless, these extensions retain the basic approach and the basic result: individuals focus exclusively on the financial incentives of the evasion gamble, and individuals pay taxes only because they fear detection and punishment.

However, it seems clear to many observers that compliance cannot be explained entirely by such purely financial considerations, especially those generated by the level of enforcement. The percentage of individual income tax returns that are subject to a thorough tax audit is generally quite small in most countries, almost always well less than 1 percent of all returns. Similarly, the penalty on even fraudulent evasion seldom exceeds more than the amount of unpaid taxes, and these penalties are infrequently imposed; civil penalties on non-fraudulent evasion are even smaller. A purely economic analysis of the evasion gamble suggests that most rational individuals should either underreport income not subject to source withholding or overclaim deductions not subject to independent verification because it is extremely unlikely that such cheating will be caught and penalized. However, even in the least compliant countries evasion seldom rises to levels predicted by a purely economic analysis, and in fact there are often substantial numbers of individuals who apparently pay all (or most) of their taxes all (or most) of the time, regardless of the financial incentives they face from the enforcement regime. ${ }^{3}$

As one way to illustrate this difficulty, denote the taxes paid by the individual on reported income as $T$, the fine on unreported taxes as $F$, the probability of detection $p$, and a fixed amount of income $I$. Then the expected utility of the individual if he or she reports no income is $p U(I-F)+(1-p) U(I)$, while the certain utility if all income is reported is $U(I-T)$. The maximum amount of taxes that the individual will voluntarily pay can be found by equating these two expressions and solving for $T$; that is; the individual will voluntarily pay taxes only until utility with full declaration equals expected utility with no declaration.

\footnotetext{
${ }^{3}$ For a somewhat contrary view, see Slemrod (2007) and Kleven et al. (2011).
} 
Using a linear approximation for the utility function (or $\left.U\left(I_{i}\right)=U(I)+U^{\prime}(I)\left(I-I_{i}\right)\right)$, the solution for $T$ is $p F$, so that taxes equal the expected value of the penalty. An individual who paid more than the expected value of the penalty is worse off than if he or she played the audit lottery. Even if the fine $F$ is as high as half of income, a low value for $p$ suggests that voluntary compliance will also be low.

The portfolio model of individual compliance behavior therefore implies that rational individuals (especially those whose incomes are not subject to third-party sources of information) should report virtually no income. Although compliance varies significantly across countries (and across taxes) and is often quite low, compliance seldom falls to a level predicted by the standard economic theory of compliance. It seems implausible that government enforcement activities alone can account for these levels of compliance; the basic model is certainly unable to explain this behavior. Indeed, the puzzle of tax compliance behavior may well be why people pay taxes, not why they evade them.

This limitation has led researchers to expand the basic model, in a search for other factors that may better explain why people pay taxes. Some of these theoretical extensions have occurred within the basic economics-of-crime approach, thereby keeping a reliance on expected utility theory. These extensions are discussed in detail by Cowell (1990), Andreoni, Erard, and Feinstein (1998), Slemrod and Yitzhaki (2002), Sandmo (2005), Slemrod (2007), and Alm (2012). These extensions add necessary realism to the basic model, while also complicating considerably the comparative statics of the compliance choice. Even so, they leave enforcement as the main factor that motivates compliance.

Importantly, there has also been some work to expand the basic model of individual choice beyond the basic economics-of-crime approach, by introducing some aspects of behavior considered explicitly by behavioral economics. These extensions follow from our earlier classification of models based both on individual framing effects (especially non-expected utility theory) and social interactions. For applications of non-expected utility theory, see Yaniv (1999), Bernasconi and Zanardi (2004), Snow and Warren (2005), and Dhami and al-Nowaihi (2007); for a detailed discussion of many of these applications to tax evasion, 
see Hashimzade, Myles, and Tran-Nam (2013). ${ }^{4}$ Relative to expected utility theory, these models change the "probability" that an individual perceives and the "objective function" that he or she pursues. In doing so, they considerably complicate the analysis of the individual decision, but they also generate predicted levels of compliance that better approximate observed levels, particularly when if they have overweighting of probabilities. For the social interactions extensions to tax evasion, see Cowell and Gordon (1988), Gordon (1989), Myles and Naylor (1996), Kim (2003), Fortin, Lacroix, and Villeval (2007), and Traxler (2010); an insightful approach is by Kirchler, Hoelzl, and Wahl (2008) in their "slippery slope" framework. These models often give "correct" predictions about the level of compliance if they allow for subjective probabilities, although (again) at the cost of considerable complexity. For general surveys of much of these literatures, see Torgler (2007) and Kirchler (2007).

Building on these extensions, here we suggest several specific avenues by which the theory of tax compliance might be extended to incorporate these behavioral notions.

Adding a Simple Loss in Utility from Cheating. An individual may suffer a loss in utility if he behaves in a manner that exhibits "unethical" behavior. Perhaps the simplest way of introducing this factor uses a "reference point" as a form of social norm, in which an individual suffers a loss in utility if some reference point is not achieved (e.g., loss aversion). The loss may be avoided by reporting all income and paying all taxes; individuals who declare less than their full income and pay less than their full taxes will suffer a loss in utility. It is straightforward to show that reported income is higher in this setting than in the basic economics-of-crime model discussed earlier. Of course, one can also imagine a setting in which an individual suffers a loss from complying with the tax code, if (say) the individual believes that paying taxes enriches a corrupt or despotic government. This alternative assumption can easily be modeled.

Adding a Loss in Utility Relative to a Social Norm. A similarly motivated approach introduces an additional element in an individual's utility function, an element that incorporates the individual's selfperception as an ethically motivated individual. Utility now becomes $U=U(I, M)$, where the term $M$ is a

\footnotetext{
${ }^{4}$ See Ariely (2012) for a discussion of behavioral methods (including experimental tests) applied to the more general issue of cheating.
} 
measure of this moral self-perception. One potentially productive way of defining $M$ is in terms of the deviation of actual reported taxes from the level with full compliance. Here the individual views paying taxes as the normal, accepted, and moral form of behavior, so that $M$ becomes a function of this difference, as in the specific function $M=M(t R-t I)=-\alpha(t R-t I)^{2}$, where $\alpha$ is a parameter. This reformulation of the individual's problem can be shown (under some conditions) to generate higher levels of compliance than in the standard model. Again, one can imagine a setting in which the social norm is to evade one's tax liabilities, due (say) to a loss of trust in public officials, the presence of official corruption, the lack of public services, the existence of friends and neighbors who cheat on their taxes, and so on. Even in such a setting, the existence of a social norm can be introduced and its effects analyzed.

Adding Loss Aversion. Another potentially fruitful modification is the incorporation of nonexpected utility behavior into the analysis (e.g., individuals exhibiting loss aversion or more extreme forms of risk aversion, such as rank dependent expected utility), which generates predictions of compliance more consistent with observed behavior (Bernasconi 1998). For individuals described by a rank dependent expected utility model, we can modify the basic maximization problem of equation (3) to one in which an individual maximizes $E U(I)=g p U\left(I_{C}\right)+(1-g)(1-p) U\left(I_{N}\right)$, where $g$ serves to overweight the probability of the "bad" outcome (or detection and punishment). This formulation can be shown to generate higher levels of compliance than the standard model of equations (1), (2), and (3). Variations on this form of nonexpected utility behavior can also be introduced.

Using a Prospect Theory Approach. One final modification to expected utility theory (among many other possible ones) incorporates all of these elements into a single framework. This approach builds upon the prospect theory of Kahneman and Tversky (1979), by introducing a value function $v($.$) and a probability$ weighting function $\pi(p)$, as discussed earlier. The value function depends upon changes in income from some reference point, rather than the level of income itself; it is also steeper for losses than for gains because a loss in income is disliked much more than an equal gain; and it is concave for gains but convex for losses; these assumptions imply that the marginal value of both gains and losses declines with their magnitude and also that the left hand derivative of the function $v^{\prime}(0)^{-}$exceeds the right hand derivative 
$v^{\prime}(0)^{+}$at the origin, where a prime denotes a derivative. The weighting function is one in which individuals overweight the low probabilities that they face in tax compliance. The relevance of these two assumptions for tax compliance is subtle yet powerful. Since some individuals frame any payment of taxes as a loss, these individuals will be likely to engage in risk-seeking behavior; that is, these individuals will declare less income than predicted by the basic model of expected utility theory. Since individuals overweight low probabilities, they systematically act as if the probability of audit that they face is much higher than its actual probability.

Prospect theory cannot explain all compliance puzzles. However, it allows a much richer analysis than is possible with expected utility theory. It allows changes in policy parameters to affect individuals differently, if their reference points differ. It explains why some people report no income even when facing a high probability of detection, if they are risk seekers or if their norm is to evade. It incorporates social interactions into the compliance decision of individuals via effects on the reference point. Given all of these factors, prospect theory suggests that compliance will often be greater than implied by most any of the extensions of expected utility theory, depending upon the nature of the social norm.

To illustrate these points, re-consider our earlier example, in which taxes paid are denoted as $T$ and

the fine on unreported taxes is denoted as $F$. The maximum amount of taxes that the individual will voluntarily pay can be found as in our earlier discussion. (Recall that under expected utility theory $T=p F$.) With a linear approximation for the value function, the solution for $T$ is $\pi(p) F$, so that an individual who overweights low probabilities will declare higher taxes than under expected utility theory. Similarly, for the case in which the individual's ethical norm is to pay taxes, it is straightforward to show that $T=\pi(p)\left[v^{\prime}(0)^{-}\right.$ $\left.v^{\prime}(0)^{+}\right] F$. Since $v^{\prime}(0)^{-}>v^{\prime}(0)^{+}$, predicted compliance increases still further.

In fact, many - if not all - of the various elements in the compliance decision are captured nicely in this last expression for $T$ : the fear of detection $(p)$ and punishment $(F)$, the overweighting of low probabilities $(\pi(p))$, and the role of ethics via reference points $\left(v^{\prime}(0)^{-} / v^{\prime}(0)^{+}\right)$.

\subsection{Testing the expanded model using experimental methods}


Testing these models in the laboratory is straightforward, and, beginning with the seminal experimental study of Friedland, Maital, and Rutenberg (1978), the basic design of most compliance experiments has been similar. Human subjects in a controlled laboratory are told that they should feel free to make as much income as possible. At the beginning of each round of the experiment, each subject is given income and must decide how much income to report. Taxes are paid at some rate on all reported, but not on underreported, income. However, underreporting is discovered with some probability, and the subject must then pay a fine on unpaid taxes. This process is repeated for a given number of rounds. At the completion of the experiment, each subject is paid an amount (the accumulated earnings) that depends on his or her performance during the experiment. Various policy changes can easily be introduced, such as changes in audit probabilities or audit rules, in penalty rates, in tax rates, in public good provision, in institutions that affect tax equity or social norms, and in many other relevant policies or institutions.

The main fiscal variables of interest in the compliance decision are audit, penalty, and tax rates, and these factors have been extensively examined. Nearly all experimental studies have found that a higher audit rate (i.e., a greater probability of audit) leads to more compliance, with an estimated reported incomeaudit rate elasticity that varies within the narrow range of 0.1 to 0.2 , although this impact appears to be nonlinear. Most studies have also found that compliance increases but only slightly with increases in the fine rate on unpaid, and that a higher marginal tax rate often (although not always) leads to less compliance. $^{5}$

Of more relevance to behavioral economics, aspects of individual framing effects have been investigated. Alm, McClelland, and Schulze (1992) demonstrate that many subjects appear to substantially overweight the probability of an audit, so that there is far more compliance than is predicted by expected utility theory. Surprisingly, Martinez-Vazquez, Harwood, and Larkins (1992) observe that compliance does not seem to be significantly affected by withholding systems, despite its potential for affecting reference

\footnotetext{
${ }^{5}$ There are also experiments that link the voluntary contributions and the compliance literatures, by allowing for a public good financed by voluntary tax payments, experiments that examine demographic factors (e.g., sex, age), and experiments that analyze alternative audit selection mechanisms. See Torgler (2002) and Alm and Jacobson (2007) for a detailed discussion of these studies.
} 
points. Subjects who find themselves unexpectedly under-withheld do not behave much differently than subjects who are correctly anticipate the under-withholding, and there is little difference in compliance between taxpayers who are under- or over-withheld.

There are also some studies on social interactions. Alm, Jackson, and McKee (1993) find that government can increase the social norm (and thereby improve compliance) by ensuring that individuals have a say in the decision process by voting on the specific way in which their taxes are to be used and by spending taxes in ways consistent with citizen preferences; that is, subjects pay more in taxes when they choose the use of their taxes by voting than when the identical use is imposed upon them, compliance is greater when the vote is decisive than when the vote is close, and compliance is significantly and dramatically lowered by the imposition of an unpopular program. Similarly, Alm, McClelland, and Schulze (1999) show that the social norm falls, often collapsing virtually to zero, when there is a social expression via group selection of the fiscal regime of a willingness to tolerate tax evasion, such as a majority vote in favor of reduced enforcement on detected evasion; however, they also find that the norm can be improved (and compliance can be increased) when there is a social expression of an unwillingness to tolerate tax evasion. Torgler (2003) and Gërxhani and Schram (2006) also find experimental evidence that that the social norm can be affected by the institutions that face individuals, by individuals' attitudes toward these institutions, and by individual participation in the selection of those institutions.

Other experiments have also demonstrated the role of social norms in compliance. Webley et al. (1991) find that individuals who have a negative attitude toward government comply less as a result. Alm, Sanchez, and de Juan (1995) find significant differences in the compliance behavior of student subjects in identical experiments but in different countries (Spain versus the United States), thereby suggesting (if not proving) that social norms toward tax compliance vary across countries and that these variations exert a measurable impact on compliance.

In other work on institutions and processes, Spicer and Thomas (1982), Friedland (1982), Spicer and Hero (1985), Beck, Davis, and Jung (1991), and Alm, Jackson, and McKee (1992) all find that institutional uncertainty about tax, penalty, and audit rates can affect compliance, although with sometimes 
offsetting effects. In earlier work, Spicer and Becker (1980) conduct experiments that suggested that perceptions of "fiscal inequity" affect compliance: compliance was lower (higher) among subjects who were told that their tax rate was higher (lower) than that of others. More recently, Alm and McKee (2004) conduct experiments in which one's chance of audit depends on one's own compliance but also on one's compliance relative to that of others in the audit pool; that is, the audit agency audits only those taxpayers thought to be the least compliant in an audit class, so that there is a "coordination game" among the taxpayers, and taxpayers will have an incentive to coordinate their reporting behavior. Their experimental results indicate that individuals typically find it difficult to coordinate their compliance decisions but that communication (or "cheap talk") among the subjects facilitates such coordination. Alm and Calvet (2013) demonstrate that individual behavior depends upon social constructs like sympathy (or an emotional response of sorrow or concern for another's wellbeing caused by the other's emotional state) and empathy (or an affective state of "putting yourself in someone else's shoes"). They use experiments to show that the presence of sympathy encourages more tax compliance and that priming to elicit empathy has a positive impact on compliance. Alm, Bloomquist, and McKee (2013) show that individuals are affected in subtle ways by the behavior of their "neighbors", or those about whom they may have information, whom they may know, or with whom they may interact on a regular basis. Their experiments find that individuals seem more likely to file and to report their taxes when they believe that other individuals are also filing and reporting their taxes; conversely, when individuals believe that others are cheating on their taxes, they become cheaters themselves. ${ }^{6}$

\footnotetext{
${ }^{6}$ Note that there are also non-experimental studies of behavioral notions. Alm and Torgler (2006) use World Values Survey data that asks individuals in a wide range of countries their attitudes toward paying taxes, and his empirical analysis demonstrates that "tax morale" differs in systematic ways across countries. Alm and Yunus (2009) examine directly whether an individual's compliance behavior depends at least in part on the decisions of others via spatial dependence (or interdependence) across taxpayers. They use state-level, time-series, cross-section data for the years 1979 to 1997 on U.S. federal individual income tax evasion to estimate the factors that affect annual per return evasion in the individual income tax. They find that there is strategic interaction among neighboring states in the determination of individual income tax evasion, so that more evasion in a neighboring state is associated with more evasion in the own state. Alm, Clark, and Leibel (2012) use previously unreleased data provided by the U.S. Internal Revenue Service on tax filing compliance. They estimate known non-filing rates for almost all 3140 counties of the United States, using as explanatory variables measures of "social capital" (or the institutions, norms, and networks that promote cooperation and enable collective action) on tax compliance. They find that non-filing is increasing in
} 
Overall, these studies demonstrate that compliance is driven by far more than the purely financial considerations of detection and punishment, but in ways that are not yet fully understood.

\section{Some applications to public budgeting}

This section examines how behavioral economics may provide insight into some of the fiscal choices often visible in public sector budgeting, with particular emphasis on the choices made in an environment of fiscal retrenchment.

\subsection{Public choice models of budgeting}

The starting point is public choice models of budgeting. ${ }^{7}$ Elected officials in a governing coalition are assumed to craft policies or packages of policies in order to be re-elected by voters. Voters in turn are assumed to assess the differential net value or "utility" delivered by that package to themselves as individuals relative to the value of the package offered by an alternative party or coalition, and they decide whether to vote or to allocate other resources such as contributions of time and money to the political process based on their assessment of the costs of participation relative to these differential net benefits. This model of voter choice assumes voter preferences are shaped by previously described qualities of rationality, unlimited willpower, and pure self-interest. However, behavioral economics suggests that voters' choices may be influenced by loss aversion, misperception of costs, the framing and context in which choices are presented, as well as intertemporal anomalies such as hyperbolic time-discounting. Adding these observations of human behavior to the basic public choice model suggests that choices in the public sphere may be shaped by both elected official anticipation of these perceptual "distortions" as well as by elected official efforts to reframe policy choices in ways that take advantage of these perceptual biases. Policymakers may reframe policy choices to help voters make "better" choices as suggested by Thaler and

heterogeneity by race and decreasing in heterogeneity by religion; they find no effect of income and language heterogeneity.

${ }^{7}$ The original formulation is based on Downs (1957), Stigler (1971), Peltzman (1976), and more recently Horn (1995) and Mueller (2003). This basic model has proven relatively robust as a starting point for the discussion of the relationship between elected officials and voters, and there is some empirical evidence that this rational choice model captures some fundamental aspects of voter behavior (Blais 2000). 
Sunstein (2008) and Sunstein (2013). This strategy may raise the issue of paternalism, but is generally grounded in the idea that policy-makers are at least focused on what they believe is the better outcome for voters. However, policy-makers may also take wish to advantage of perceptual biases to give voters "something for nothing", avoiding tough policy choices. Some key biases include those associated with fiscal illusion, loss aversion, loss aversion relative to a perceived reference point, and anomalies in time discounting.

Theories of fiscal illusion are grounded in information asymmetry (and associated transaction costs of obtaining information). Here voters only perceive the immediate tax price of public goods and do not recognize future liens against their assets. This "fiscal illusion" allows elected officials to issue debt, run deficits, or fail to provide for long term liabilities and appear to provide something for nothing (Buchanan 1964; Alesina and Perotti 1995).

Another behavioral economics notion important for budgeting theory is "loss aversion". The general assumption in the classic public choice model is that elected officials choose a package of goods without reference to voters' initial endowment of goods and further that a loss does not generate a more intense response from voters than a gain of similar magnitude. However, a central finding in behavioral economics is that the intensity of preferences is more influenced by a loss than by a gain of comparable magnitude. Preference asymmetry associated with loss aversion is widely documented (Tversky and Kahneman 1991; Kahneman, Knetsch, and Thaler 1986; Camerer and Lowenstein 2004; Thaler 1999), and forms the foundation for explaining a number of market anomalies, such as the equity premium puzzle (Benartzi and Thaler 1995) or illiquidity in housing markets when there is a decline in housing prices (Genesove and Mayer 2001).

Added to the public choice model, loss aversion would mean that a voter who perceives that he is going to experience a loss in the benefit package proposed by an elected official is more likely to engage the political process than the voter who perceives that he is going to gain a comparable amount. Voters will also perceive loss relative to a reference point. Commonly observed reference points include "current endowment", even if only suggested or recently established (Tversky and Kahneman 1991; Kahneman, 
Knetsch, and Thaler 1990), nominal wages or funding levels (Tversky and Kahneman 1986; Shafir, Diamond, and Tversky 1997), expected levels of funding or in some cases expected reduced levels of funding (Kahneman and Tversky 1979; Kahneman, Knetsch, and Thaler 1991).

An important and relevant behavioral economics premise relates to discounting. Voters may discount gains and losses in a quasi-hyperbolic fashion. When presented with a choice between an immediate gain or loss traded off against one in the future, people appear to discount future consumption at a much higher rate than predicted by classic discounted utility theory (Laibson 1997; O’Donoghue and Rabin 1999) (Loewenstein and Prelec 1992; Frederick, Loewenstein, and O’Donoghue 2002). ${ }^{8}$ Importantly, this effect appears to diminish when immediacy is lost and the tradeoff between two goods is considered at a more distant time in the future; in this instance, a constant positive discount rate is essentially reestablished.

Given fiscal illusion, loss aversion, and the susceptibility of people to various distortions in evaluating their choices, theorists have observed that firms and employers will anticipate these distortions and act strategically based on this knowledge. For instance, firms appear to intuit that shareholders will have more disutility from a loss than a comparable gain, and this knowledge systematically affects earnings reports (Thaler 1999). Firms anticipate that customers look at current prices as a reference point and may retaliate if prices are raised in response to increased demand. Thus prices are set high and when lowered are only lowered "temporarily", through sales and discounts, which keeps the customer reference point the same (Kahneman, Knetsch, and Thaler 1986). Along the same lines, elected officials may also anticipate these perceptual biases and act accordingly.

Although there are myriad implications of these (and other) behavioral economics notions, we focus on how a political economy model modified by the observations from behavioral economics might be used to predict the choices of elected officials in a cutback budgeting environment. Some strategic behaviors that derive from commonly observed distortions in perception include: using the nominal current

\footnotetext{
${ }^{8}$ An important exception to this finding is that in experimental studies many individuals, when presented with an immediate loss now versus a certain loss in the future, tend to prefer to take the loss immediately (Thaler 1981; Loewenstein and Prelec 1993). This anomaly is discussed more in the section on time discounting.
} 
endowment as a baseline; establishing reductions relative to a common reference point; and preserving current consumption at the expense of future consumption. Each is considered.

\subsection{Using the current endowment as a baseline}

As discussed earlier, experimental studies have shown that people anchor on nominal or historical values. For instance, a person would be happier with a two percent raise when there is four percent inflation than they would be with a two percent cut when there is no inflation (Shafir, Diamond, and Tversky 1997). In fact, a nominal wage cut is generally perceived as unfair even if the market value of labor has declined. This observation has been used to explain the stickiness of wages and further why adjustments in real wages appear to be greater in inflationary periods than in periods of stable prices: because the adjustments can be made without the perception of a "loss" (Kahneman, Knetsch, and Thaler 1991; Kahneman, Knetsch, and Thaler 1986; Shafir, Diamond, and Tversky 1997).

This anchoring on nominal values extends beyond labor markets and appears to affect consumer perceptions of the price of goods and in turn induces firms to act strategically to avoid visiting a perceived loss upon consumers. Kahneman, Knetsch, and Thaler (1986) use this to explain the prevalence of companies offering "discounts" rather than pure price reductions (so that when they "raise" prices later, the consumer will simply perceive that the reference price has remained constant) and further theorize that when demand increases for a good, there will be shortages because firms will not be able to raise prices in response to increases in demand.

The extension to public sector budgeting is that voters are likely to "anchor" on the current level of spending, assuming the jurisdiction does not actively change this reference point (discussed below). This suggests that elected officials will prefer to cut budgets by using the erosion of inflation rather than making targeted cuts to specific programs. A potential effect of this form of cut is that it may have an uneven impact across the budget as programs that have "slack" or are less efficient will be better able to absorb this cut than programs that are underfunded or run more efficiently. Elected officials may also fail to provide for growth in demand or provide too little for such programs since this type of cut by omission will be less 
visible than direct cuts. Such a policy will favor programs with low growth in demand and cause degradation in provision for programs with high growth in demand.

These predictions assume that a jurisdiction uses prior year spending as a baseline; however, not surprisingly, those who intuit that the baseline is important may try to change it. For instance, 22 states in the U.S. as well as the federal government use some form of "current services" baseline. These current services baselines may build in inflationary adjustment, growth in population, and other annualizers (McNichol and Grundman 2011). An interesting question is whether policy-makers may be changing the voter reference points upward and therefore any effort to make a reduction in spending by failing to fund inflation or growth in demand will appear to voters as a loss. Research on state budgets has shown that states with current services baselines have an annual growth rate of half a percentage point more than states with a prior year baseline (Crain 1998).

Not surprisingly, the current debates over the U.S. federal baseline indicate that key interest groups as well as policy-makers anticipate this shift in perception. Groups that advocate for reductions in government spending condemn federal "baseline budgeting" which builds growth factors into the base (Editorial Board 2012; Citizens Against Government Waste 2013), while groups that support government programs advocate for baselines that reflect automatic growth (Kogan 2012; McNichol and Grundman 2011).

The theoretical idea that voters will anchor on prior year spending or an artificially established baseline has other implications for fiscal retrenchment. In periods of fiscal stress, policy-makers may be more likely to pull back on all new initiatives that have not yet been psychologically absorbed into the “current endowment." Pulling back on new initiatives has been observed in several case studies of budgetary responses in the face of an initial fiscal crisis (Bifulco and Duncombe 2010; Conant 2003; Bourdeaux 2012).

Finally, an obvious baseline endowment is a job. A widely observed governmental cutback strategy is saving money through hiring freezes and attrition (Levine, Rubin, and Wolohojian 1981; Greenhalgh and McKersie 1980; Wolman 1980; Stanley 1980; Hoene and Pagano 2009, 2010). There is no experienced 
direct loss through reductions in force and savings are recouped from unused "slack" from vacancies. Much as with the erosion of a budget from failing to fund inflationary increases or increases in service demand, erosion through employee attrition may also have a distortionary effect. Agencies with employees that are more marketable or have more turn over may be unduly affected by this type of strategy.

\subsection{Establishing reductions relative to a common reference point: Fairness as a cutback strategy}

While more complicated than the ideas around baselines, policy-makers may also try to establish a common reference level expectation for cuts, often in reference to notions of "fairness". Experimental studies suggest that employees will accept wage cuts if they perceive some exogenous factor has affected their employer's profit margin, while they will not accept wage cuts if there is simply a decline in wages. Similarly, consumers expect firms to keep the price of goods constant, unless the cost of inputs goes up which affects the firm's profit margin. Again, changes in demand for a product are not considered a fair reason to increase prices. How this would map to the public sector where there is no "profit" is not entirely clear. Presumably there are conditions under which everyone understands that the budget must be cut. How much wages or prices can change in response to pressure on profits is also not entirely clear, but other evidence indicates that employees look at their peers as a reference point for a fair wage and consumers look to the prices of comparable goods. Kahneman, Knetsch, and Thaler (1986) hypothesize that firms have to generally maintain parity for the price of goods that are part of a family of goods and similarly wages have to be maintained roughly in parity for similar jobs to meet standards of fairness. For instance, sports teams cannot differentially price tickets for ballgames depending on the level of demand that they anticipate for different games. Employers cannot pay one employee vastly more than another employee doing exactly the same job even though one employee may be much more valuable. As a result, the most valuable employees are always in demand and prone to leave and there are shortages of tickets to sporting events that are the most popular. 
While not a perfect analogue to public sector budgets, the general concept that people accept some cuts as "fair" (and use reference points to establish fairness) provides some evidence that policy-makers pick "across the board cuts" because they are perceived as "fair cuts". Alternatively, policy-makers may establish a reference percentage cut by program or agency. Certainly across the board cuts are often observed as a public sector fiscal strategy (Levine 1979; Wolman 1980; Levine, Rubin, and Wolohojian 1981; National Association of State Budget Officers 2009, 2010). Similarly pay cuts and furloughs may be applied on a uniform basis across budgets (although often some key services will be protected) (Bourdeaux 2012).

\subsection{Preserving current consumption at the expense of future consumption: Anomalies in time discounting}

A further application of behavioral economics to public sector budgeting occurs in the observed anomalies in discounting. As noted earlier, people do not engage in exponential discounting but instead engage in discounting that is better described by a quasi-hyperbolic functional form; that is, the discount rate appears to be very high when a person has to choose between a benefit/cost immediately when judged against a benefit/cost in the future.

This construct is used to explain a variety of personal behaviors that are close analogues to governmental choices about debt spending or "borrowing" from the future. Anomalies at the personal level that are particularly analogous to governmental borrowing include: failing to make retirement investments, both because of a preference for current consumption and an expectation that one's future self will make up the difference(Laibson 1998, 1997; Laibson, Repetto, and Tobacman 1998); failing to adjust current consumption downward to accommodate an anticipated future decline in income - creating larger out year "cliffs" when income actually falls (Shea 1995); and running up credit card debt or taking out home equity loans to finance current consumption (Laibson 1997). In this context, Laibson (1997) points out that some people appear to engage in seemingly irrational activities that create unnecessary liquidity constraints on 
themselves such as Christmas clubs and that this may simply be a way of credibly committing their future selves to savings.

Governmental failures to provide sufficiently for future liabilities such pensions and retiree health care benefits are widely documented (Pew Center on the States 2010, 2011). Additionally, a host of strategies that have the effect of creating "debt" or out year liabilities in order to preserve current consumption are commonly observed (and much bemoaned), both in good times and in times of fiscal stress (Petersen 2003; Bifulco et al. 2012; Alesina and Perotti 1995; State Budget Crisis Task Force 2012).

If voters show similar behaviors in their choices about public goods as they show in their choices about private goods, then it follows that voters are not being deceived by elected officials who are engaged in "fiscal illusion." Instead, voters are complicit in governmental activities that push costs into the future. They treat payment for public goods much as they treat private goods, demanding immediate benefits and applying a high discount rate to the future cost/lost benefits. If so, this has some different implications for policy remedies than fiscal illusion. Fiscal illusion suggests that voters need easier access to information. Hyperbolic discounting suggests that information costs are less the problem than a human tendency to be overoptimistic about future savings behaviors, and further suggests that a "sophisticated voter" might even be willing to pay for a policy that pre-commits the voter to a healthier savings pattern despite associated higher costs.

\section{A specific application to public budgeting: Policy during fiscal retrenchment}

One of the implications of applying behavioral models to public sector budgeting is that public sector fiscal retrenchment should be dominated by efforts to avoid perception of loss. If voters feel loss more keenly than a comparable gain, and at the same time they fail to perceive some types of losses (such as those resulting from the erosion of inflation), then it would not be surprising to see elected officials strategically take advantage of these distortions in perception during periods of cutback budgeting. Public 
sector budgeting literature catalogues many strategies used to balance budgets but there is no unified theoretical idea about which strategies dominate the choice set of public officials.

Bourdeaux (2012) makes an initial effort to examine more closely policy-maker choices in a period of fiscal retrenchment. Traditional budgeting cuts, as described in such outlets as the National Association of State Budget Officers and the National Conference of State Legislatures, include: cuts that make use of reserves or surpluses, programmatic cuts (e.g., across the board cuts, targeted cuts, program termination), personnel-based cuts (e.g., hiring freezes, attrition, layoffs, salary and benefit cuts, early retirement incentives), cost-shifting to the future, intergovernmental strategies (e.g., devolving responsibilities to lower levels of government, soliciting resources from higher levels of government), and improvements in efficiency. However, our application of behavioral economics suggests that some of these strategies are more likely to be chosen than others. Budgetary cutback strategies can be classified based on the extent to which they reflect some identified mechanism for obscuring voter perception of loss or whether they are pure cuts to the base and likely to be perceived as a loss. Strategies that might obscure a cut include reductions from failing to account for inflation or growth in service demand, hiring freezes and attrition, pulling back on new initiatives, pushing costs into the future, and across the board cuts. Strategies that are more transparent and more likely to be perceived as "unfair" include closing facilities, layoffs, and elimination or reduction of specific programs.

Table 1 summarizes these budget cutting strategies, and classifies them along two dimensions: the extent to which the strategies represent actual cuts to the budget versus the extent to which the perception of loss to voters or key constituency groups is mitigated by the nature of the cut. Quadrant I strategies are ones where there is no real cut and also no perceived loss. In effect, the government can get away with reducing funding without any impact on agency operations. Most obvious are situations where the state can simply draw on reserves, slack, or intergovernmental funds to avoid a cut. A more complicated Quadrant I strategy is finding a pure efficiency gain. Quadrant II strategies are often criticized in the public budgeting literature, but are also the ones that behavioral economics suggests policy-makers will be most likely to choose after or in tandem with the Quadrant I options. For example, constituencies will be less likely to 
perceive a loss if costs are pushed into the future; this suggests a range of strategies including using debt to pay for operating costs, accounting shifts to push costs into the future or to recognize revenues sooner and expenses later, cuts to capital outlay, maintenance, and professional development, and cuts less than a baseline reduction. People will perceive loss relative to a baseline, which in many state budgets is the prior year funding. Also, a gain foregone is less likely to be perceived as a loss. In sum, Quadrant II cuts may not really be perceived as cuts or may be seen as "fair cuts." Quadrant III strategies are ones where there is not a real cut that will affect service provision but constituencies may perceive a cut, such as a situation where funding formulas or cost of living adjustments (COLAs) might decline when service demand or inflation declines. Finally, Quadrant IV strategies are cuts that are fully perceived as cuts. These include elimination of programs, cuts to the base/targeted cuts to specific policies or programs, layoffs, and salary cuts. One would expect that Quadrant IV strategies would generally be avoided by policy-makers because they will draw the most controversy and will be the most difficult to sustain through a political process. However, these types of cuts are often perceived as the most desirable to make from a purely rationale policy perspective, and they align with notions of cutting unproductive programs or scaling back less essential government operations.

Bourdeaux (2012) tests these notions against the State of Georgia's FY2009 Amended and FY2010 General budget deliberations, a period of significant fiscal stress for the state. For the 2009 legislative session, the Governor and the state legislature had to cover a $\$ 2.7$ billion shortfall from the current year 2009 budget (a 13 percent gap from current services projections); in FY 2010, the shortfall was $\$ 3.7$ billion (a 17 percent gap). Bourdeaux (2012) examines the recommendations made by the agencies, the Governor's proposals, and the final conference committee reports, and codes these various choices according to the typology in Table 1. She finds that transparent and direct cuts to baseline services (or those in Quadrant IV) were a minor strategy for the state. As summarized in Table 2 for FY 2010 only, these "cuts with a non-mitigated perception of loss" made up at most 15 percent of the state's overall strategy for cutting the budget, and in fact this FY10 amount was largely dominated by a single cut eliminating a local 
property tax relief grant. Additionally, her analysis finds that direct cuts were also more likely to be reversed during the political process.

\section{Conclusions: Some future directions}

We believe that behavioral economics has considerably expanded our understanding of many dimensions of the public sector. We now know much more about individual decisions in a rich array of dimensions. Indeed, to date the main purpose of behavioral economics has been to understand how people make decisions. The applications to public budgeting are newer but equally insightful. Accordingly, we conclude by discussing - and predicting - several areas in behavioral economics to which its future application to the analysis of the public sector seem particularly valuable. These areas fall into five main categories: testing new areas of individual behavior, including attempts to explain empirical anomalies; developing new theories of individual behavior, likely by incorporating other social sciences and even other disciplines; moving beyond individual decisions to the aggregation of individual decisions to group behavior; incorporating behavioral economics with dynamic analysis; and using the insights of behavioral economics to design optimal government policies.

In the first area - testing new areas of individual behavior - there are many dimensions of individual behavior that can be usefully examined but that so far remain largely unexplored. Do individuals respond differently:

- To a tax credit versus an equivalent tax deduction?

- To a tax discount from a "high" tax base versus an equivalent tax surcharge from a "low" base?

- To a tax change framed as a percentage change versus as an absolute (dollar) change?

- To a tax change defined in terms of their own tax liability only versus an equivalent tax change that compares their change to that of others?

- To the timing of a tax change (e.g., one "large" change versus many equivalent "small" changes)?

- To an ongoing (e.g., monthly) tax withholding versus an equivalent one-time payment?

- To savings programs that have "commitment" or "heuristic" devices (e.g., forced payroll savings plans) versus programs with only "traditional" financial incentives? 
Extending the analysis from taxes to government transfer policies (including social insurance programs) seems quite promising. The basic issue here is how individuals are affected in their tax-and transfer-related decisions by such behavioral notions as saliency, mental accounting, discounting, and context.

Note that there are some empirical inconsistencies in behavioral economics theories of individual behavior, inconsistencies that represent fruitful areas of research. Of particular note are those associated with time discounting. Experimental studies or surveys that ask recipients whether they would rather absorb a cost now or at a future point find that people would rather pay a cost earlier (or immediately) rather than later. These results are attributed to the negative utility of anticipation of loss (or "dread"), and suggest a small or even negative discount rate for losses as compared to gains (Thaler 1981; Frederick, Loewenstein, and O'Donoghue 2002; Loewenstein and Prelec 1992). How this finding reconciles with the theory and common observation that people will procrastinate on an unpleasant task even if it means that delay will make a future task is even more unpleasant is not entirely clear.

Another anomaly is that people often prefer improving sequences of events to declining sequences of events even if the net present value is less in the first instance. This sequencing bias directly conflicts with quasi hyperbolic discounting in both the gain and loss scenarios. Loewenstein and Prelec (1993) suggest a way to reconcile this for rewards, but there is no clear theoretical direction of the implications for loss. However, the theoretical ideas around gains may have implications for loss scenarios. Examining responses to different types of sequencing of rewards, Loewenstein and Prelec (1993) find that people respond differently to sequences that have "integrity" (or are closed ended and certain) than to sequences that are more open ended. In particular, people are more impatient and tend to exhibit more hyperbolic discounting in reward scenarios that are open ended. For instance, in an experimental setting when people are offered a hypothetical voucher to a nice restaurant, those who are given a discrete time frame in which they can use the vouchers (e.g., two years) actually propose to wait longer to use the vouchers than those who are given an open ended period in which they can use the vouchers (Loewenstein and Prelec 1993). This may apply to the loss scenarios as well. In the experimental or survey settings where this theory has been tested, the loss scenarios are certain and clearly defined, so that the sequence had integrity 
(MacKeigan et al. 1993; Redelmeier and Heller 1993). In many real world scenarios, the time period during which someone has to absorb a loss created by borrowing is somewhat indeterminate. People may be less likely to want to absorb a cost when the day of reckoning is indeterminate and the actual amount of reckoning is uncertain or alternatively is a "gain foregone" rather than a clear loss.

A second area for future research in behavioral economics involves incorporating in new theories of behavior the insights from other social sciences (e.g., sociology and anthropology) and even from other disciplines (e.g., philosophy, religion, neuroscience), in order to understand better which features of naturally occurring settings are likely to affect individual (and group) decisions. For example, the notion of "reciprocity" (i.e., responding to a positive action with another positive action, responding to a negative action with another negative action) arises in large part from anthropology, and that of "adherence to group norms" from sociology. Using these alternative perspectives to human behavior cannot help but expand our understanding of individual behavior, as demonstrated most clearly in Akerlof and Kranton (2000) and Akerlof and Shiller (2009). In the development of these new theories, we believe that there will be growing recognition and acceptance that one theory may not fit all individuals at all times, or even the same individual at different times. Individuals in their infinite variety exhibit a "full house" of behaviors, behaviors that cannot be neatly captured by a single methodology. We also believe that these new theories will be largely outside the mainstream of economics.

Indeed, in this regard "neuroscience" (or the science of how the brain works) is using images of brain activity and other techniques to generate direct measurements of thoughts and feelings, and these measurements are allowing researchers to determine which areas of the brain are active in which types of decision processes. The goal is to allow "neuroeconomics" to understand what may seem to be suboptimal or illogical decisions. As discussed by Camerer, Loewenstein, and Prelec (2005), Glimcher et al. (2008), and Glimcher (2009), this work is changing the way in which we think about how people make decisions, by identifying brain structures that process key elements of utility theory when people face uncertainty or ambiguity. 
More broadly, this second area recognizes the dependence of any social system on a range of individual motivations and social institutions beyond those deemed important in standard economic analysis. Indeed, there is a school of thought that argues that our market economy depends upon moral "virtues" all of which help motivate and guide individuals in their many activities and that help in the proper functioning of any system. As noted earlier, Adam Smith recognized the importance of virtues in The Theory of Moral Sentiments, which has one section ("Of the Character of Virtue") that focuses on the virtues of benevolence and self-command. Similarly, Max Weber emphasized virtues in his 1905 classic work The Protestant Ethic and the Spirit of Capitalism.

Now in Western traditions, there are commonly thought to be seven virtues: Faith, Hope, Love, Justice, Courage, Prudence, and Temperance. Of these, the standard economic view of behavior is based mainly on Prudence (which assumes an ability to judge and so is tied to the calculation of the benefits and costs of individual choices) and also on Temperance (which assumes moderation and foresight). Beyond these two virtues, the rekindling of interest in virtues as essential elements in human behavior has reached public economics mainly in some aspects of Love (via altruism) and of Justice (via fairness); to our knowledge, notions of virtues have not yet reached public budgeting. Even so, other virtues remain largely unexplored, and other aspects of Love and Justice also remain unexamined. Indeed, there may well be other "virtues" that merit examination, such as Wisdom (or creativity, curiosity, open-mindedness, love of learning, perspective), Humanity (or kindness, social intelligence), and Transcendence (or appreciation of beauty and excellence, gratitude, hope, humor, and spirituality.

As argued by Feinstein (2006), a focus on virtues connects naturally with behavioral economics, and he suggests a promising approach to modeling these virtues, an approach that might usefully be applied to the analysis of the public sector. This approach starts with individual behavior, in which an individual who has internalized a virtue might evaluate each possible choice in terms of how close it comes to the ideal behavior for which the virtue calls, and then might weigh this distance as one factor in his or her decision, together with other traditional utility factors; when multiple virtues are involved, as is typically 
the case, the individual might evaluate the distance of each possibility from these virtues using a weighting metric of some kind. There are of course other approaches that can be pursued.

A third area involves moving from individual decisions to the aggregate behavior of the group, via a specific focus on social interactions. ${ }^{9}$ Ultimately, better understanding of individual decisions allows better understanding of group behavior. Behavioral economics allows us to identify which features of naturally occurring settings are likely to affect group decisions. For example, as noted earlier, social interactions are a crucial consideration in charitable donations: someone is watching as one makes a gift, people are judging each other's actions, and somebody is asking for the gift. In such a setting, the nature of these social interactions emerges as a major factor in giving. However, social influences on behavior are strong in virtually all areas of behavior.

The fourth area combines behavioral methods with the "new dynamic public finance" (Kocherlakota 2010). Most dynamic modeling assumes that agents obey the standard assumptions in neoclassical economics, that they are rational, possess unlimited willpower, and are self-interested. Combining behavioral notions like non-standard preferences, imperfect optimization, and bounded selfcontrol with dynamic considerations will be quite challenging. Even so, these extensions seem likely to generate more accurate predictions of the intertemporal evolution of behavior. One already fruitful line of research in these areas is "agent-based modeling". Bloomquist (2011) uses this approach, calibrating the model to observations from laboratory experiments, in order to simulate evolutionary changes in compliance that parallel real-world experiences.

A final area involves uses the results of all of these largely positive analyses to devise to design optimal government policies (e.g., normative analyses). As noted earlier, behavioral economics provides a new justification for government intervention in markets since there may well be welfare gains from government policies even in markets that do not exhibit externalities, public goods, asymmetric

\footnotetext{
${ }^{9}$ There is in fact some experimental work on aggregate or market behavior, including experimental tests of tax incidence in competitive and in imperfectly competitive markets and tests of tax equivalence propositions. For example, see Kachelmeier, Limberg, and Schadewald (1994, Quirmbach, Swenson, and Vines (1996), Kerschbamer and Kirchsteiger (2000), and Ruffle (2005).
} 
information, or imperfect competition. The design of optimal government policies in these circumstances is particularly challenging. However, Gruber and Koszegi (2004), O’Donoghue and Rabin (2006), and Chetty, Looney, and Kroft (2009) demonstrate that such normative analysis is possible, especially in the context of "sin" taxes. Bernheim and Rangel (2009) provide an insightful framework for these analyses.

A complicating factor in this social interactions research is whose preferences actually matter and require modeling. Consider public budgeting. In public choice theory, there are dueling ideas about whether to focus on the median voter or interest groups or both (Mueller 2003). The Downs (1956) original model of the political economy of public sector choices develops a complex schema of different types of voters who are willing to apply different levels of resources to the political process. Numerous empirical observations of political processes suggest that some groups clearly have more influence over political processes than others (Stone 1989; Sbragia 1996; Levine, Rubin, and Wolohojian 1981), and theorists hypothesize that those groups who are able to solve the collective action problems of organization are better able to generate resources to influence the political processes (Olson 1965; Stigler 1971; Peltzman 1976; Horn 1995). Further, in a cutback environment, some of the strategies suggested above may be more likely to be perceived as a loss by public sector employees as opposed to external voters. Agencies in turn may be able to buffer the impact of cuts on actual services depending on strategic choices made internal to their organization. Finally, research on consumers and employers shows that they act on norms of fairness even in the absence of potential retaliation. For instance, surveys of tipping behavior suggest that people leave the same percentage tip in a restaurant that they frequent as in a restaurant to which they never expect to return (Kahneman, Knetsch, and Thaler 1986). Applying these insights to public budgeting suggests that elected officials do not intuit voter concerns so much as they have internalized norms of fairness or perhaps it is they themselves who feel a sense of loss when making a cut. These are issues to consider in further theory development or empirical assessments.

A closely related complication is the complexity of interactions in a political system. Typically, systems are heavily influenced by groups and their group dynamics, which may counteract or alter the behavioral effects that are documented at an individual level. For instance, savvy interest groups may 
educate their membership about the implications of different fiscal outcomes. The complexity of such human interactions is a challenge to all aspects of the application of behavioral economics to the public sector, including both public economics and public budgeting. Ultimately, in a complex system theorists have to simplify and assume that there is "noise" in any model, and empiricists have to recognize propensities towards a particular action rather than certainty that a particular result will occur in all cases.

In short, we believe that the future prospects for behavioral economics to the public sector are exciting and unlimited. The challenges here are twofold: to design theories that are realistic but nevertheless tractable enough to generate clear predictions, and then to develop tests of these theories that allow the independent causal effects of policies to be identified and distinguished from other observationally equivalent theories. Testing these theories will require much creativity. Laboratory experiments seem likely to continue to play a decisive role in testing (and even in developing) these individual theories. Controlled field experiments are also a promising avenue of testing individual theories. Given the complexity of many of these theories, especially in their aggregate form, tests of aggregate behavior will necessarily be forced to use numerical simulation methods. Agent-based models seem likely to emerge as a leading tool here. In any event, the record of recent developments in behavioral economics indicates that these challenges can be met.

\section{REFERENCES}

Abaluck, Jason T. and Jonathan Gruber (2009). "Choice Inconsistencies among the Elderly: Evidence from Plan Choice in the Medicare Part D. Program." Cambridge, MA: NBER Working Paper 14759.

Ainslie, George (1975). "Specious Reward: A Behavioral Theory of Impulsiveness and Impulse Control." Psychological Bulletin, 82 (4): 463-496.

Ainslie, George (1991). "Derivation of 'Rational' Economic Behavior from Hyperbolic Discount Curves." The American Economic Review, 81 (1): 134-140.

Akerlof, George A. (1980). "A Theory of Social Custom, of Which Unemployment May be One Consequence." The Quarterly Journal of Economics, 94 (4): 749-775.

Akerlof, George A. and Rachel E. Kranton (2000). "Economics and Identity." The Quarterly Journal of Economics, 115 (3): 715-753.

Akerlof, George A. and Robert J. Shiller (2009). Animal Spirits: How Human Psychology Drives the Economy and Why It Matters. Princeton University Press, Princeton, NJ.

Alesina, Alberto, and Roberto Perotti (1995). "The Political Economy of Public Deficits." International Monetary Fund Staff Papers, 42 (1): 1-31. 
Allingham, Michael G. and Agnar Sandmo (1972). "Income Tax Evasion: A Theoretical Analysis." Journal of Public Economics, 1 (3-4): 323-338.

Alm, James (2012). "Measuring, Explaining, and Controlling Tax Evasion: Lessons from Theory, Field Studies, and Experiments." International Tax and Public Finance, 19 (1): 54-77.

Alm, James, Kim Bloomquist, and Michael McKee (2013). "When You Know Your Neighbor Pays Taxes: Peer Effects and Taxpayer Compliance.” New Orleans, LA: Tulane University Working Paper.

Alm, James and Roberta D. Calvet (2013). "Sympathy, Empathy, and Tax Compliance." Journal of Economic Psychology, forthcoming.

Alm, James, Todd Cherry, Michael Jones, and Michael McKee (2010). "Tax Information Assistance Services and Tax Compliance Behavior.” Journal of Economic Psychology, 31 (4): 577-586.

Alm, James, Betty R. Jackson, and Michael McKee (1992). "Institutional Uncertainty and Taxpayer Compliance." The American Economic Review, 82 (4): 1018-1026.

Alm, James, Betty R. Jackson, and Michael McKee (1993). "Fiscal Exchange, Collective Decision Institutions, and Tax Compliance." Journal of Economic Behavior and Organization, 22 (4): 285303.

Alm, James and Sarah Jacobson (2007). "Using Laboratory Experiments in Public Economics." National Tax Journal, 60 (1): 129-152.

Alm, James, Gary H. McClelland, and William D. Schulze (1991). "Why Do People Pay Taxes?” Journal of Public Economics, 48 (1): 21-38.

Alm, James, Gary H. McClelland, and William D. Schulze (1999). "Changing the Social Norm of Tax Compliance by Voting." Kyklos, 52 (2): 141-171.

Alm, James and Michael McKee (2004). "Tax Compliance as a Coordination Game." Journal of Economic Behavior and Organization, 54 (3): 297-312.

Alm, James, Isabel Sanchez, and Ana de Juan (1995). "Economic and Noneconomic Factors in Tax Compliance." Kyklos, 48 (1): 3-18.

Alm, James and Mohammad Yunus (2009). "Spatiality and Persistence in U.S. Individual Income Tax Compliance." National Tax Journal, 62 (1): 101-124.

Andreoni, James (1989). "Giving with Impure Altruism: Applications to Charity and Ricardian Equivalence." The Journal of Political Economy, 97 (6): 1447-1458.

Andreoni, James (1990). "Impure Altruism and Donations to Public Goods: A Theory of Warm-glow Giving." Economic Journal, 100 (401): 464-477.

Andreoni, James (1995). "Cooperation in Public Goods Experiments: Kindness or Confusion?" The American Economic Review, 85 (4): 891-904.

Andreoni, James and B. Douglas Bernheim (2009). "Social Image and the 50-50 Norm: A Theoretical and Experimental Analysis of Audience Effects." Econometrica, 77 (5): 1607-1636.

Andreoni, James, Brian Erard and Jonathan Feinstein (1998). "Tax Compliance." The Journal of Economic Literature, 36 (2): 818-860.

Andreoni, James and John Miller (2002). "Giving According to GARP: An Experimental Test of the Rationality of Altruism." Econometrica, 70 (2): 737-753.

Andreoni, James and Abigail Payne (2013). "Charitable Giving." In Alan Auerbach, Raj Chetty, Martin Feldstein, and Emmanuel Saez (eds.), Handbook of Public Economics, Volume 5. Amsterdam, The Netherlands: Elsevier Publishing, forthcoming.

Andreoni, James and Justin Rao (2011). "The Power of Asking: How Communication Affects Selfishness, Empathy, and Altruism.” Journal of Public Economics, 95 (7-8): 513-520.

Angner, Erik and George Loewenstein (2010). "Behavioral Economics." In Uskali Mäki (ed.), Handbook of the Philosophy of Science, Volume 13, 67-101. Amsterdam, The Netherlands: Elsevier Publishing.

Ariely, Dan (2008). Predictably Irrational The Hidden Forces That Shape Our Decisions. New York, NY: Harper Collins.

Ariely, Dan (2012). The (Honest) Truth about Dishonesty. New York, NY: Harper Collins. 
Baron, Jonathan and Edward J. McCaffery (2003). "The Humpty Dumpty Blues: Disaggregation Bias in the Evaluation of Tax Systems." Organization Behavior and Human Decision Processes, 91 (2): 230-242.

Bayer, Patrick J., B. Douglas Bernheim, and John Karl Scholz (2009). "The Effects of Financial Education in the Workplace: Evidence from a Survey of Employers." Economic Inquiry, 47 (4): 605-624.

Beck, Paul, Jon Davis, and Woon-Oh Jung (1991). "Uncertainty and Taxpayer Aggressiveness: Experimental Evidence." The Accounting Review, 66 (3): 535-558.

Becker, Gary S. (1962). "Irrational Behavior and Economic Theory." The Journal of Political Economy, 70 (1): $1-13$.

Becker, Gary S. (1974). “A Theory of Social Interactions.” The Journal of Political Economy, 82 (6): 10631093.

Benartzi, Shlomo and Richard Thaler (1995). "Myopic Loss-aversion and the Equity Premium Puzzle." The Quarterly Journal of Economics, 110 (1): 73-92.

Bergstrom, Theodore, Laurence Blume, and Hal Varian (1986). "On the Private Provision of Public Goods." Journal of Public Economics, 29 (1): 25-49.

Bernasconi, Michele (1998). "Tax Evasion and Orders of Risk Aversion.” Journal of Public Economics, 67 (2): 123-134.

Bernasconi, Michele and Alberto Zanardi (2004). "Tax Evasion, Tax Rates, and Reference Dependence." FinanzArchiv, 60 (3): 422-445.

Bernheim, B. Douglas (1994). “A Theory of Conformity.” The Journal of Political Economy, 102 (5): 841877.

Bernheim, D. Douglas and Daniel M. Garrett (2003). "The Effects of Financial Education in the Workplace: Evidence from a Survey of Households." Journal of Public Economics, 87 (7-9): 14871519.

Bernheim, D. Douglas, Daniel M. Garrett, and Dean Maki (2001). "Education and Saving: The Long-term Effects of High School Financial Curriculum Mandates." Journal of Public Economics, 88 (3): 435-465.

Bernheim, B. Douglas (2009). "On the Potential of Neuroeconomics: A Critical (but Hopeful) Appraisal." American Economic Journal: Microeconomics, 1 (2): 1-41.

Bernheim, B. Douglas and Antonio Rangel (2009). "Beyond Revealed Preference: Choice-theoretic Foundations for Behavioral Welfare Economics." The Quarterly Journal of Economics, 124 (1): 51-104.

Bettinger, Eric, J. Bridget Terry Long, Philip Oreopoulos, and Lisa Sanbonmatsu (2009). "The Role of Simplification and Information in College Decisions: Results from the FAFSA Experiment." Cambridge, MA: NBER Working Paper 15361.

Bifulco, Robert, Beverly Bunch, William Duncombe, Mark Robbins, and William Simonsen (2012). "Debt and Deception: How States Avoid Making Hard Fiscal Decisions." Public Administration Review, 72 (5): 659-667.

Bifulco, Robert and William Duncombe (2010). "Budget Deficits in the States: New York." Public Budgeting \& Finance, 30 (1): 58-79.

Blais, Andre (2000). To Vote or Not to Vote: The Merits and Limits of Rational Choice Theory. Pittsburgh, PA: University of Pittsburgh Press.

Bloomquist, Kim M. (2011). "Tax Compliance as an Evolutionary Coordination Game: An Agent-Based Approach.” Public Finance Review, 39 (1): 25-49.

Blumkin,Tomer, Bradley J. Ruffle, and Yosef Ganun (2008). "Are Income and Consumption Taxes Ever Really Equivalent? Evidence from a Real-effort Experiment with Real Goods." Munich, Germany: University of Munich, CESifo Working Paper No. 2194.

Bolton, Gary E. and Axel Ockenfels (2000). "ERC: A Theory of Equity, Reciprocity and Competition." The American Economic Review, 90 (1): 166-193.

Boulding, Kenneth E. (1958). "Contemporary Economic Research". In Donald P. Ray (ed.), Trends in Social Science, 9-26. New York, NY: Philosophical Library. 
Bourdeaux, Carolyn J. (2012). "The Political Economy of Cutting Budgets.” Association for Budgeting and Financial Management Annual Conference. New York, NY.

Bradley, Sebastian (2013). "Property Tax Salience and Payment Delinquency." Philadelphia, PA: Drexel University Working Paper.

Buchanan, James M. (1964). "Public Debt, Cost Theory, and Fiscal Illusion.” In James M. Ferguson (ed.), Public Debt and Future Generations, 150-162. Chapel Hill, NC: The Univerity of North Carolina Press.

Cabral, Marika and Caroline Hoxby (2012). "The Hated Property Tax: Salience, Tax Rates and Tax Revolts." Cambridge, MA: NBER Working Paper No. 18514.

Camerer, Colin F. and George F. Loewenstein (2004). "Behavioral Economics: Past, Present and Future." In Colin F. Camerer, George F. Loewenstein, and Matthew Rabin (eds.), Advances in Behavioral Economics, 1-61. Princeton, NJ: Russell Sage Foundation and Princeton University Press.

Camerer, Colin F., George F. Loewenstein, and Drazen Prelec (2005). "Neuroeconomics: How Neuroscience Can Inform Economics." The Journal of Economic Literature, 43 (1): 9-64.

Card, David and Michael Ransom (2011). "Pension Plan Characteristics and Framing Effects in Employee Saving Behavior." The Review of Economics and Statistics, 93 (1): 228-243.

Carroll, Gabriel, James J. Choi, David I. Laibson, Brigitte C. Madrian, and Andrew Metrick (2009). "Optimal Defaults and Active Decisions: Theory and Evidence from 401(k) Saving." The Quarterly Journal of Economics, 124 (4): 1639-1674.

Chetty, Raj (2012). "Bounds on Elasticities with Optimization Frictions: A Synthesis of Micro and Macro Evidence on Labor Supply." Econometrica, 80 (3): 969-1018.

Chetty, Raj, John N. Friedman, Soren Leth-Peteren, Rorben Nielsen, and Tore Olsen (2013). "Active versus Passive Decisions and Crowd-out in Retirement Savings Accounts: Evidence from Denmark." The Quarterly Journal of Economics, forthcoming.

Chetty, Raj, John N. Friedman, and Emmanuel Saez (2013). "Using Differences in Knowledge Across Neighborhoods to Uncover the Impacts of the EITC on Earnings." The American Economic Review, forthcoming.

Chetty, Raj and Emmanuel Saez (2013). "Teaching the Tax Code: Earnings Responses to an Experiment with EITC Recipients.” The American Economic Journal: Applied Economics, 5 (1): 1-31.

Chetty, Raj, Adam Looney, and Kory Kroft (2009). "Salience and Taxation: Theory and Evidence." The American Economic Review, 99 (4): 1145-1177.

Choi, James J., David I. Laibson, and Brigitte C. Madrian (2009). "Mental Accounting in Portfolio Choice: Evidence from a Flypaper Effect." The American Economic Review, 99 (5): 2085-2095.

Citizens Against Government Waste (2013). Baseline Budgeting 2013. Available online at http://cagw.org/content/baseline-budgeting.

Clotfelter, Charles T. (1985). Federal Tax Policy and Charitable Giving. Chicago, IL: University of Chicago Press.

Coleman, James A. (1990). Foundations of Social Theory. Cambridge, MA: Belknap.

Conant, James K. (2003). "Wisconsin's Budget Deficit: Size, Causes, Remedies, and Consequences." Public Budgeting \& Finance, 23 (2): 5-38.

Congdon, William J., Jeffrey R. Kling, and Sendhil Mullainathan (2011). Policy and Choice - Public Finance through the Lens of Behavioral Economics. Washington, D.C.: The Brookings Institution Press.

Cowell, Frank A. (1990). Cheating the Government: The Economics of Evasion. Cambridge, MA: The MIT Press.

Cowell, Frank A. and James P. F. Gordon (1988). "Unwillingness to Pay." Journal of Public Economics, 36 (3): 305-321.

Cox, James C., Daniel Friedman, and Vjollca Sadiraj (2008). "Revealed Altruism.” Econometrica, 76 (1): 31-69.

Crain, W. Mark, and Nicole Verrier Crain (1998). "Fiscal Consequences of Budget Baselines." Journal of Public Economics, 67 (3): 421-436. 
DellaVigna, Stefano (2009). "Psychology and Economics: Evidence from the Field." The Journal of Economic Literature, 47 (2): 315-372.

DellaVigna, Stefano, John A. List, and Ulrike Malmendier (2012). "Testing for Altruism and Social Pressure in Charitable Giving." The Quarterly Journal of Economics, 127 (1): 1-56.

de Bartolome, Charles A. M. (1995). "Which Tax Rate Do People Use: Average or Marginal?" Journal of Public Economics, 56 (1): 79-96.

Dhami, Sanjit and Ali al-Nowaihi (2007). "Why Do People Pay Taxes? Prospect Theory versus Expected Utility Theory." Journal of Economic Behavior and Organization, 64 (1): 171-192.

Downs, Anthony (1957). An Economic Theory of Democracy. New York, NY: HarperCollins Publishers.

Duflo, Esther, Willilam Gale, Jeffrey Liebman, Peter Orszag, and Emmanuel Saez (2006). "Saving Incentives for Low- and Middle-income Families: Evidnce from a Field Experiment with H\&R Block." The Quarterly Journal of Economics, 121 (4): 1311-1346.

Duflo, Esther and Emmanuel Saez (2003). "The Role of Information and Social Interactions in Retirement Plan Decisions: Evidence from a Randomized Experiment." The Quarterly Journal of Economics, 118 (3): 815-842,

Dynarski, Susan and Judith Scott-Clayton (2006). "The Cost of Complexity in Federal Student Aid." National Tax Journal, 59 (2): 319-356.

Editorial Board (2012). "The Budget Baseline Con: How Washington Fools the Public about Spending 'cuts'." The Wall Street Journal (Review \& Outlook), 4 December 2012.

Elster, Jon (1989). The Cement of Society - A Study of Social Order. Cambridge, UK: Cambridge University Press.

Fehr, Ernst and Klaus M. Schmidt (1999). "A Theory of Fairness, Competition, and Cooperation." The Quarterly Journal of Economics, 114 (3): 817-868.

Feinstein, Jonathan S. (2006). The Nature of Creative Development. Stanford, CA: Stanford University Press.

Finkelstein, Amy (2009). “EZ Tax: Tax Salience and Tax Rates.” The Quarterly Journal of Economics, 124 (3): 969-1010.

Fong, Christina M. and Erso F. P. Luttmer (2011). "Do Race and Fairness Matter in Generosity? Evidence from a Nationally Representative Charity Experiment." Journal of Public Economics, 95 (5-6): 372-394.

Fortin, Bernard, Guy Lacroix, and Marie-Claire Villeval (2007). "Tax Evasion and Social Interactions." Journal of Public Economics, 91 (8): 2089-2112.

Frederick, Shane, George F. Loewenstein, and Ted O'Donoghue (2002). "Time Discounting and Time Preference: A Critical Review." The Journal of Economic Literature, 40 (2): 351-401.

Friedland, Nehemiah, Schlomo Maital, and Aryen Rutenberg (1978). “A Simulation Study of Income Tax Evasion.” Journal of Public Economics, 10 (1): 107-116.

Friedland, Nehemiah (1982). "A Note on Tax Evasion as a Function of the Quality of Information about the Credibility of Threatened Fines: Some Preliminary Research." Journal of Applied Social Psychology, 12 (55): 54-59.

Genesove, David and Christopher Mayer (2001). "Loss Aversion and Seller Behavior: Evidence from the Housing Market." The Quarterly Journal of Economics, 116 (4): 1233-1260.

Gërxhani, Klarita and Arthur Schram (2006). "Tax Evasion and Income Source: A Comparative Experimental Study." Journal of Economic Psychology, 27 (3): 402-422.

Glaeser, Edward L. (2004). "Psychology and the Market." The American Economic Review Papers and Proceedings, 94 (2): 408-413.

Glaeser, Edward L. (2006). "Paternalism and Psychology." The University of Chicago Law Review, 73 (1): 133-156.

Glimcher, Paul W. (2011). Foundations of Neuroeconomic Analysis. New York, NY: Oxford University Press.

Glimcher, Paul W., Colin F. Camerer, Russell A. Poldrack, and Ernst Fehr (2008), Neuroeconomics: Decision Making and the Brain. New York, NY: Academic Press. 
Gneezy, Uri and John A. List (2006). "Putting Behavioral Economics to Work: Testing for Gift Exchange in Labor Markets Using Field Experiments." Econometrica, 74 (5): 1365-1384

Gordon, James P.F. (1989). "Individual Morality and Reputation Costs as Deterrents to Tax Evasion." European Economic Review, 33 (4): 797-805.

Gould, Stephen J. (1996). Full House. New York, NY: Harmony Books.

Greenhalgh, Leonard and Robert B. McKersie (1980). "Cost-effectiveness of Alternative Strategies for Cut-back Management." Public Administration Review, 40 (6): 575-584.

Hashimzade, Nigar, Gareth D. Myles, and Binh Tran-Nam (2013). "Applications of Behavioural Economics to Tax Evasion." Journal of Economic Surveys, forthcoming.

Hoene, Christopher and Michael Pagano (2009). "City Fiscal Conditions in 2009." In Research Brief on America's Cities. Washington, D.C.: National League of Cities.

Hoene, Christopher and Michael Pagano (2010). "City Fiscal Conditions in 2010." In Research Brief on America's Cities. Washington, D.C.: National League of Cities.

Homans, George C. (1961). Social Behavior. New York, NY: Harcourt Brace and World.

Horn, Murray J. (1995). The Political Economy of Public Administration - Institutional Choice in the Public Sector. New York, NY: Cambridge University Press.

Hungerman, Daniel M. (2009). "Crowd Out and Diversity." Journal of Public Economics, 93 (6): 729-740.

Kachelmeier, Steven J., Stephen T. Limberg, and Michael S. Schadewald (1994). "Experimental Evidence of Market Reactions to New Consumption Taxes." Contemporary Accounting Research, 10 (2): $505-545$.

Kahneman, Daniel (2011). Thinking, Fast and Slow. New York, NY: Farrar, Straus and Giroux.

Kahneman, Daniel, Jack L. Knetsch, and Richard H. Thaler (1986). "Fairness as a Constraint on Profit Seeking: Entitlements in the Market." The American Economic Review, 76 (4):728-741.

Kahneman, Daniel, Jack L. Knetsch, and Richard H. Thaler (1990). "Experimental Tests of the Endowment Effect and the Coase Theorem.” The Journal of Political Economy, 98 (6): 1325-1348.

Kahneman, Daniel, Jack L. Knetsch, and Richard H. Thaler (1991). "Anomalies: The Endowment Effect, Loss Aversion, and Status Quo Bias.” The Journal of Economic Perspectives, 5 (1): 193-206.

Kahneman, Daniel and Amos Tversky (1979). "Prospect Theory: An Analysis of Decision under Risk." Econometrica,47 (2): 263-292.

Karlan, Dean and John A. List (2007). "Does Price Matter in Charitable Giving? Evidence from a LargeScale Natural Field Experiment." The American Economic Review, 97 (5): 1774-1793.

Karlan, Dean, Margaret McConnell, Sendhil Mullainathan, and Jonathan Zinman (2010). "Getting to the Top of Mind: How Reminders Increase Saving." Cambridge, MA: NBER Working Paper 16205.

Kerschbamer, Rudolf and Georg Kirchsteiger (2000). "Theoretically Robust but Empirically Invalid? An Experimental Investigation into Tax Equivalence.” Economic Theory, 16 (3): 719-734.

Kim, Youngse (2003). "Income Distribution and Equilibrium Multiplicity in a Stigma-based Model of Tax Evasion." Journal of Public Economics, 87 (9): 1591-1616.

Kirchler, Erich (2007). The Economic Psychology of Taxation. Cambridge, UK: Cambridge University Press.

Kirchler, Erich, Erik Hoelzl, and Ingrid Wahl (2008). "Enforced Versus Voluntary Tax Compliance: The 'Slippery Slope' Framework." Journal of Economic Psychology, 29 (2): 210-225.

Kleven, Henrik J., Martin B. Knudsen, Claus T. Kreiner, Søren Pedersen, and Emmanuel Saez (2011). "Unwilling or Unable to Cheat? Evidence from a Randomized Tax Audit Experiment in Denmark." Econometrica, 79 (3): 651-692.

Kling, Jeffrey R., Sendhil Mullainathan, Eldar Shafer, Lee Vermeulen, and Marian V. Wrobel (2009). "Misperception in Choosing Medicare Drug Plans." Cambridge, MA: Harvard University Working Paper.

Kocherlakota, Narayana R. (2011). The New Dynamic Public Finance. Princeton, NJ: Princeton University Press.

Kogan, Richard (2012). "Baseline Reform Act is a Step in the Wrong Direction.” Washington, D.C.: Center on Budget and Policy Priorities. 
Laibson, David I. (1997). "Golden Eggs and Hyperbolic Discounting." The Quarterly Journal of Economics, 112 (2): 443-477.

Laibson, David I. (1998). "Life-cycle Consumption and Hyperbolic Discount Functions." European Economic Review, 42 (4): 861-871.

Laibson, David I., Andrea Repetto, and Jeremy Tobacman (1998). "Self Control and Saving for Retirement." Brookings Papers on Economic Activity, 1998 (1): 91-172.

Landry, Craig, Andreas Lange, John A. List, Michael K. Price, and Nicholas G. Rupp (2006). "Toward an Understanding of the Economics of Charity: Evidence from a Field Experiment." The Quarterly Journal of Economics, 121 (2): 747-782.

Landry, Craig, Andreas Lange, John A. List, Michael K. Price, and Nicholas G. Rupp (2010). "Is a Donor in Hand Better than Two in the Bush? Evidence from a Natural Field Experiment." The American Economic Review, 100 (3): 958-983.

Ledyard, John O. (1995). "Public Goods: A Survey of Experimental Research." In John H. Kagel and Alvin E. Roth (eds.), The Handbook of Experimental Economics, 111-194. Princeton, NJ: Princeton University Press.

Levine, Charles H. (1979). "More on Cutback Management: Hard Questions for Hard Times." Public Administration Review, 39 (2): 179-183.

Levine, Charles H., Irene Rubin, and George Wolohojian (1981). The Politics of Retrenchment: How Local Governments Manage Fiscal Stress. London, UK: Sage Publications.

List, John A. and David Lucking-Reiley (2002). "The Effects of Seed Money and Refunds on Charitable Giving: Experimental Evidence from a University Capital Campaign." The Journal of Political Economy, 110 (8): 215-233.

List, John A. and Michael K. Price (2009). "The Role of Social Connections in Charitable Fundraising: Evidence from a Natural Field Experiment." Journal of Economic Behavior and Organization, 69 (2): 160-169.

Loewenstein, George F. and Drazen Prelec (1992). "Anomalies in Intertemporal Choice: Evidence and an Interpretation”. The Quarterly Journal of Economics, 107 (2): 573-597.

Loewenstein, George F. and Drazen Prelec (1993). "Preferences for Sequences of Outcomes." Psychological Review, 100 (1): 91-108.

MacKeigan, Linda D., Lon N. Larson, JoLaine R. Draugalis, J. Lyle Bootman, and Lawton R. Burns (1993). "Time Preference for Health Gains Versus Health Losses." PharmacoEconomics, 3 (5): 374-386.

Madrian, Brigitte C. and Dennis F. Shea (2001). "The Power of Suggestion: Inertia in 401(k) Participation and Savings Behavior." The Quarterly Journal of Economics, 116 (4): 1149-1187.

Maital, Shlomo (1986). "Prometheus Rebound: On Welfare-improving Constraints". Eastern Economic Journal, 12 (3): 337-344.

Martinez-Vazquez, Jorge, Gordon B. Harwood, and Ernest R. Larkins (1992). "Withholding Position and Income Tax Compliance: Some Experimental Evidence.” Public Finance Review, 20 (2): 152174.

McCaffery, Edward J. and Joel Slemrod (eds.) (2006). Behavioral Public Finance. New York, NY: Russell Sage Foundation.

McNichol, Elizabethand Dylan Grundman (2011). "The Current Services Baseline: A Tool for Understanding Budget Choices." Washington, D.C.: Center on Budget and Policy Priorities.

Mueller, Dennis (2003). Public Choice III. Cambridge, UK: Cambridge University Press.

Myles, Gareth D. and Robin A. Naylor (1996). "A Model of Tax Evasion with Group Conformity and Social Customs." European Journal of Political Economy, 12 (1): 49-66.

National Association of State Budget Officers (2009). Fiscal Survey of the States. Washington, D.C.

National Association of State Budget Officers (2010). Fiscal Survey of the States. Washington, D.C.

National Conference of State Legislatures (2010). State Budget Update: March 2010. Denver, CO: National Conference of State Legislatures. 
O’Donoghue, Ted, and Matthew Rabin (1999). "Doing It Now or Later." The American Economic Review, 89 (1): 103-124.

Olson, Mancur (1965). The Logic of Collective Action: Public Goods and the Theory of Groups. Cambridge, MA: Harvard University Press.

Peltzman, Sam (1976). "Toward a More General Theory of Regulation.” Journal of Law and Economics, 211 (19): 211-240.

Petersen, John E. (2003). "Changing Red to Black: Deficit Closing Alchemy." National Tax Journal, 56 (3): $567-577$.

Pew Center on the States (2010). "The Trillion Dollar Gap: Underfunded State Retirement Systems and the Roads to Reform." Washington, D.C.: Pew Charitable Trusts.

Pew Center on the States (2011). "The Widening Gap: The Great Recession's Impact on State Pension and Retiree Health Care Costs." Washington, D.C.: Pew Charitable Trusts.

Quirmbach, Herman C., Charles W. Swenson, and Cynthia C. Vines (1996). "An Experimental Examination of General Equilibrium Tax Incidence.” Journal of Public Economics, 61 (3): 337358.

Rabin, Matthew (1993). "Incorporating Fairness into Game Theory and Economics." The American Economic Review, 83 (5): 1281-302.

Rabin, Matthew (1998). "Psychology and Economics." The Journal of Economic Literature, 36 (1): 11-46.

Redelmeier, Donald A.and Daniel N. Heller (1993). "Time Preference in Medical Decision Making and Cost-effectiveness Analysis." Medical Decision Making, 13 (3): 212-217.

Roberts, Russell D. (1984). "A Positive Model of Private Charity and Wealth Transfers." The Journal of Political Economy, 92 (1): 136-148.

Ruffle, Bradley (2005). "Tax and Subsidy Incidence Equivalence Theories: Experimental Evidence from Competitive Markets." Journal of Public Economics, 89 (8): 1519-1542.

Samuelson, Paul A. (1954). "The Pure Theory of Public Expenditure." The Review of Economics and Statistics, 36 (4): 387-389.

Sandmo, Agnar ( 2005). "The Theory of Tax Evasion: A Retrospective View." National Tax Journal, 58 (4): 643-663.

Sausgruber, Rupert and Jean-Robert Tyran (2005). "Testing the Mill Hypothesis of Fiscal Illusion." Public Choice, 122 (1-2): 39-68.

Sbragia, Alberta (1996). Debt Wish: Entrepreneurial Cities, U.S. Federalism, and Economic Development. Pittsburgh, PA: University of Pittsburgh Press.

Schelling, Thomas C. (1984). "Self-command in Practice, in Policy, and in a Theory of Rational Choice." The American Economic Review, 74 (1): 1-11.

Shafir, Eldar, Peter Diamond, and Amos Tversky (1997). "Money Illusion." The Quarterly Journal of Economics, 112 (2): 341-374.

Shea, John (1995). "Union Contracts and the Life-cycle/Permanent-income Hypothesis." The American Economic Review, 85 (1): 186-200.

Shefrin, Hersh M. and Richard H. Thaler (1988). "The Behavioral Life-cycle Hypothesis." Economic Inquiry, 26 (4): 609-643.

Simon, Herbert (1955). "A Behavioral Model of Rational Choice." The Quarterly Journal of Economics, 69 (1): 99-118.

Slemrod, Joel (2007). "Cheating Ourselves: The Economics of Tax Evasion." The Journal of Economic Perspectives, 21 (1): 25-48.

Slemrod, Joel and Shlomo Yitzhaki (2002). "Tax Avoidance, Evasion, and Administration." In Alan J. Auerbach and Martin Feldstein (eds.), Handbook of Public Economics, 1423-1470. Amsterdam, London, and New York: Elsevier Publishing.

Snow, Arthur and Ronald S. Warren (2005). "Ambiguity about Audit Probability, Tax Compliance, and Taxpayer Welfare." Economic Inquiry, 43 (4): 865-871.

Spicer, Michael W. and Lee A. Becker (1980). "Fiscal Inequity and Tax Evasion: An Experimental Approach.” National Tax Journal, 33 (2): 171-175. 
Spicer, Michael W. and Rodney E. Hero (1985). “Tax Evasion and Heuristics: A Research Note.” Journal of Public Economics, 26 (2): 263-267.

Spicer, Michael W. and J. Everett Thomas (1982). "Audit Probabilities and the Tax Evasion Decision: An Experimental Approach." Journal of Economic Psychology, 2 (3): 241-245.

Stanley, David T. (1980). "Cities in Trouble." In Charles Levine (ed.), Managing Fiscal Stress: The Crisis in the Public Sector, 95-122. Chatham, New Jersey: Chatham House Publishers, Inc.

State Budget Crisis Task Force (2012). Report of the State Budget Crisis Taskforce. New York, NY.

Stigler, George J. (1971). "The Theory of Economic Regulation." The Bell Journal of Economics and Management Science, 2 (1): 3-21.

Stone, Clarence (1989). Regime Politics: Governing Atlanta, 1946-1988. Lawrence, KS: University Press of Kansas.

Sugden, Robert (1984). "Reciprocity: The Supply of Public Goods through Voluntary Contributions." Economic Journal, 94 (376): 772-787.

Sunstein, Cass R. (2013). Simpler - The Future of Government. New York, NY: Simon and Schuster.

Thaler, Richard H. (1981). "Some Empirical Evidence of Dynamic Inconsistency." Economic Letters, 8 (3): 201-207.

Thaler, Richard H. (1999). "Mental Accounting Matters.” Journal of Behavioral Decision Making, 12 (3): 183-206.

Thaler, Richard H. and Hersh M. Shefrin (1981). "An Economic Theory of Self-control." The Journal of Political Economy, 89 (2): 392-406.

Thaler, Richard H. and Cass R. Sunstein (2008). Nudge - Improving Decisions about Health, Wealth, and Happiness. New Haven, CN: Yale University Press.

Thaler, Richard H. and Shlomo Benartzi (2004). "Save More Tomorrow: Using Behavioral Economics to Increase Employee Saving." The Journal of Political Economy, 112 (S1): S164-S187.

Torgler, Benno (2002). "Speaking to Theorists and Searching for Facts: Tax Morale and Tax Compliance in Experiments." Journal of Economic Surveys, 16 (5): 657-683.

Torgler, Benno (2003). "Beyond Punishment: A Tax Compliance Experiment with Taxpayers in Costa Rica." Revista de Análisis Económico, 18 (1): 27-56.

Torgler, Benno (2007). Tax Compliance and Tax Morale: A Theoretical and Empirical Analysis. Northampton, MA: Edward Elgar Publishing Inc.

Traxler, Christian (2010). "Social Norms and Conditional Cooperative Taxpayers." European Journal of Political Economy, 26 (1): 89-103.

Tversky, Amos and Daniel Kahneman (1986). "Rational Choice and the Framing of Decisions." The Journal of Business, 59 (4): S251-S278.

Tversky, Amos and Daniel Kahneman (1991). "Loss Aversion in Riskless Choice: A Reference-Dependent Model.” The Quarterly Journal of Economics, 106 (4): 1039-1061.

Ullmann-Margalit, Edna (1977). The Emergence of Norms. Oxford, NY: Clarendon Press.

Warr, Peter G. (1982). "Pareto Optimal Redistribution and Private Charity." Journal of Public Economics, 19 (1): 131-138.

Webley, Paul, Henry S. J. Robben, Henk Elffers, and Dick J. Hessing (1991). Tax Evasion: An Experimental Approach, European Monographs on Social Psychology. Cambridge, UK: Cambridge University Press.

Wilkinson, Nick (2007). An Introduction to Behavioral Economics A Guide for Students. New York, NY: Palgrave Macmillan.

Wolman, Harold (1980). "Local Government Strategies to Cope with Fiscal Pressure." In Charles H. Levine and Irene Rubin (eds.), Fiscal Stress and Public Policy, 231-248. Beverly Hills, CA: Sage Publications.

Yaniv, Gideon (1999). "Tax Compliance and Advanced Tax Payments: A Prospect Theory Analysis." National Tax Journal, 52 (4): 753-764.

Young, H. Peyton (1998). "Social Norms and Economic Welfare." European Economic Review, 41 (3-5): 821-830. 
Table 1: Matrix of Cutback Budgeting Options

\begin{tabular}{|c|c|c|}
\hline & No Cut & Cut \\
\hline $\begin{array}{l}\text { Non-mitigated Perception } \\
\text { of Loss/Perceived Loss }\end{array}$ & $\begin{array}{l}\text { Quadrant III: No Cut But with Perception of Loss } \\
\text { - Cut Salaries in Deflationary Environment Below } \\
\text { the Rate of Deflation. }\end{array}$ & $\begin{array}{l}\text { Quadrant IV: Cut with Non-mitigated Perception of Loss } \\
\text { - Cut Employee Compensation } \\
\text { - Impose Layoffs } \\
\text { - Impose Furloughs } \\
\text { - Impose Selected Programmatic "Cuts to the Base" or Selected } \\
\text { - Programmatic Cuts over "Equity" Baseline } \\
\text { Eliminate Programs }\end{array}$ \\
\hline
\end{tabular}

Source: Bourdeaux (2012). 
Table 2: State of Georgia Budget Cutting Strategies for FY2010

\begin{tabular}{|l|c|c|c|}
\hline Strategy & $\begin{array}{c}\text { Agency Request } \\
\text { (percent of total) }\end{array}$ & $\begin{array}{c}\text { Governor's Recommendation } \\
\text { (percent of total) }\end{array}$ & $\begin{array}{c}\text { Conference Committee } \\
\text { (percent of total) }\end{array}$ \\
\hline Quadrant I: No Cut with No Perceived Loss & $17 \%$ & $42 \%$ & $46 \%$ \\
\hline Quadrant II: Cut with Mitigated Perception of Loss & $56 \%$ & $38 \%$ & $39 \%$ \\
\hline Quadrant III: No Cut But with Perception of Loss & $0 \%$ & $0 \%$ & $0 \%$ \\
\hline Quadrant IV: Cut with Non-mitigated Perception of Loss & $28 \%$ & $20 \%$ & $15 \%$ \\
\hline Total Cuts (\$ millions) & $\$ 1,070.6$ million & $\$ 4,611.9$ million & $\$ 4,635.4$ million \\
\hline
\end{tabular}

Source: Bourdeaux (2012) 